\title{
Determinants of Liquidity (Re-)Allocation and the Decision to Cross-List or Cross-Delist ${ }^{*}$
}

\author{
Roland Füss ${ }^{\dagger}$, Ulrich Hommel ${ }^{\S}$, and Jan-Carl Plagge
}

Working Paper

This version: March 2016

Acknowledgement: The authors are grateful to Keith Cuthbertson (the editor) and anonymous referees for valuable suggestions which have significantly improved the article. We are also indebted to Madhucchand Darbha and the participants of the 2013 Annual Meeting of the European Financial Management Association (EFMA) for valuable comments. The usual disclaimer applies.

$\dagger$ Corresponding author: Swiss Institute of Banking and Finance (s/bf), University of St.Gallen, Rosenbergstrasse 52, CH-9000 St. Gallen, Switzerland and ZEW Mannheim, Germany, Phone: +41 71224 7010, Fax: +41 71224 7088, E-mail: roland.fuess@unisg.ch.

$\S$ Department of Finance and Accounting, EBS Business School, EBS Universität für Wirtschaft und Recht, Gustav-Stresemann-Ring 3, D-65189 Wiesbaden, Germany, Phone: +49611 7102 1241, Fax: +49 6117102 101241, E-mail: ulrich.hommel@ebs.edu.

¥ Department of Finance and Accounting, EBS Business School, EBS Universität für Wirtschaft und Recht, Gustav-Stresemann-Ring 3, D-65189 Wiesbaden, Germany, +49 6117102 1246, Fax: +49 6117102 101246; E-mail: jcplagge@aol.com. 


\title{
Determinants of Liquidity (Re-)Allocation and the Decision to Cross-List or Cross-Delist
}

\begin{abstract}
This paper examines the factors influencing the liquidity allocation between local and foreign dual listings. Based on a comprehensive data set covering the period between 2001 and 2011, empirical results suggest that the fraction of trading in the foreign listing decreases with a higher degree of stock market integration measured as the stock price correlation with the world market. Furthermore, the analysis of individual cross-listings reveals that both an improvement of a country's state of economic development and a better regulatory environment significantly affect the allocation of trading. While an improvement in economic development increases both, local and foreign liquidity, a strengthening of regulatory standards leads to a decrease in trading volumes at foreign exchanges. Finally, the liquidity share in the foreign listing is found to decrease over time, a trend which turns out to be driven by developing rather than by developed markets.
\end{abstract}

Keywords: $\quad$ Cross-listing; capital market regulation; economic development; liquidity allocation; market integration.

JEL-Classification: $\quad$ G12, G15 


\section{Introduction}

Many companies around the world have started to cross-list their shares in the form of depository receipts (DRs) on well-known international stock exchanges in order to improve access to integrated capital markets. ${ }^{1}$ Typical cross-listing motives are higher liquidity, more investor recognition, and a decrease in the cost of capital. In recent years, however, some corporations have decided to reverse this move and terminate their dual listing. The most often-cited reasons are broadly related to the development of the depository receipt's liquidity. While some companies decide to terminate their dual listing due to poor liquidity development, others fear that the foreign listing might become too successful, which in turn could lead to a reallocation of liquidity away from the home market and consequently to a decrease in local visibility. ${ }^{2}$

Our analysis aims at identifying the factors that explain liquidity shifts between home and foreign stock markets. ${ }^{3}$ Rising DR liquidity can be taken as an indicator of a foreign listing's success due to an increased use of secondary listings by market participants. In contrast, if liquidity remains at a low level or even dries up over time, it can be interpreted as a sign of investor lack of interest.

The literature points to two major determinants of the liquidity allocation in cross-listed stocks: capital market segmentation and liquidity concentration. Market segmentation seems

\footnotetext{
${ }^{1}$ This paper focuses on American Depository Receipts (ADRs) and Global Depository Receipts (GDRs), still or formerly cross-listed on U.S. and U.K. stock exchanges.

${ }^{2}$ Companies from developed parts of Europe and Asia primarily consider low trading volume as the primary reason for delisting (Sanyo Electric, a technology company locally listed on the Tokyo Stock Exchange (TSE), has, for example, mentioned "extremely low" trading volume in its press statement as the main reason for announcing the delisting (released on August 30, 2006)). Knight and Pretty (2005) analyze 325 Latin American DR programs and find that for most Mexican and Chilean companies the "expectation that liquidity in the home market may be diminished by trading in the DR" is the driving motivation for a delisting (Knight and Pretty (2005:1).

${ }^{3}$ Liquidity is defined as the aggregated trading value in monetary units in a given stock over a pre-defined period of time.
} 
to always work in favor of the DR program since international investors can more easily invest via a foreign listing. ${ }^{4}$ However, the impact of liquidity concentration is less clear. One would expect that, in the absence of extreme differences in trading and transaction costs, liquidity will tend to concentrate on one exchange, either local or the foreign. ${ }^{5}$ The development of the local capital market would then play a key role in determining the direction of liquidity concentration.

This paper is the first to simultaneously measure and explicitly disentangle the effects stemming from (1) the stage of economic development, (2) the regulatory environment, (3) the development of the local capital market, and (4) the degree of integration of a company's local market into the international capital market. While related studies, such as Halling et al. (2008), primarily focus on the relationship between foreign and local liquidity, this paper additionally considers the liquidity reactions of both foreign and local liquidity separately. ${ }^{6}$

The empirical results show that the fraction of trading in the foreign listing decreases with a higher degree of stock market integration, which is defined in this study as the stock price correlation with the world market. The analysis of individual cross-listings further

\footnotetext{
${ }^{4}$ If direct or indirect investment barriers with regard to a given local market exist, a dual listing on an international exchange may turn formerly restricted international investors into unrestricted investors. In this context, Smith and Sofianos (1997) find that the aggregated trading volume of the foreign and the local listing significantly increases for corporations that cross-list on U.S. stock exchanges. If investment barriers start to decline and markets integrate, however, liquidity should re-concentrate locally where the information density with regard to a given stock should be the highest (see, e.g., Halling et al. (2008)).

${ }^{5}$ According to Pagano (1989), liquidity should concentrate in one market if "trade is equally costly across markets" (Pagano, 1989:255). If the number of market participants increases in one market, a potential loss associated with the liquidation of a given asset decreases. A decrease in indirect transaction costs, in turn, should attract more market participants which would further increase liquidity.

${ }^{6}$ The related variables used by Halling et al. (2008) are shareholder protection, measured on the basis of anti-director rights, a measure for insider trading law enforcement and financial development defined as market capitalization scaled by GDP. These measures relate to the development of the local market and the regulatory environment, but do not explicitly capture economic development and market integration. Halling et al. (2008) examine the trading activity of the local listing in order to understand liquidity behavior around the cross-listing date. They do not investigate foreign liquidity separately.
} 
reveals that both an improvement of a country's economic development as well as a better regulatory environment affect the allocation of trade. While an increase in economic development primarily increases both, local and foreign liquidity, an improvement in regulatory standards leads to a decrease in foreign trading. In addition, the ratio of foreign to local liquidity, measured relative to the initial cross-listing date, decreases over time. A closer inspection of the liquidity development in foreign and local markets reveals that the relative liquidity (re)allocation is primarily shaped by the decrease in foreign liquidity of firms domiciled in emerging markets. Splitting the sample into firms domiciled in developed, emerging, and frontier markets shows that the decrease in foreign liquidity is, in turn, driven by cross-listings of companies domiciled in emerging markets. As liquidity across the entire sample is more highly concentrated in the local rather than the foreign listing, the trend of a liquidity reallocation towards the local listing is in line with the concentration hypothesis. It states that trading tends to agglomerate on the exchange that offers relative informational advantages for traders. This is typically the local exchange, where information density is presumably the highest.

The identification of the underlying factors driving the liquidity allocation between local and foreign listings is of essential importance for companies that face a choice of whether to cross-list in a foreign market. As pointed out by Amihud et al. (2005), illiquidity in the form of transaction costs has a direct influence on firm value. According to their reasoning, the price discount due to illiquidity equals the present value of the expected stream of transaction costs throughout the lifetime of an investment. The higher these costs are, the higher are also the future expected returns and the lower is the present value of a company. Chordia et al. (2000) find a positive relationship between transaction costs and trading volume. Thus, liquidity as an indirect proxy for transaction costs has a direct influence on share prices and, in turn, on the value of a cross-listed company. The findings are also of 
interest for financial institutions such as ETF providers, which offer products based on depository receipts. As our analysis suggests, the derived benefits are only of a transitory nature given that the liquidity in the foreign listing tends to decrease over time. Finally, Chan et al. (2008) find that foreign listings are traded at a premium over the underlying stock, which increases (decreases) depending on the liquidity of the foreign (local) listing. Thus, market participants are willing to pay a price for liquidity. The results of our study enable companies to better anticipate such a potential premium ex ante.

The rest of the paper is structured as follows: The next section presents the various rationales explaining why companies may decide to cross-list their shares in a foreign market and why a substantial number of companies have recently decided to terminate their crosslisting. Section 3 derives the testable hypotheses based on the general discussion of the determinants of liquidity allocation. Section 4 describes the data and the estimation approach. The empirical results, including several robustness tests, are presented and interpreted in Section 5. Section 6 concludes.

\section{Motives for Listing and De-Listing Depository Receipts}

\subsection{Reasons to Cross-List}

A considerable number of theories have been developed to explain why companies decide to cross-list their shares. The majority of them can be traced back to a few underlying hypotheses:

Market segmentation hypothesis: Bekaert and Harvey (1995) argue that "markets are completely integrated if assets with the same risk have identical expected returns irrespective of the market. ${ }^{7}[\ldots]$ If the market is segmented from the rest of the world, its covariance with

\footnotetext{
${ }^{7}$ In a similar vein, Jorion and Schwarz (1986) define financial integration as a state in which investors
} earn the same risk-adjusted expected return on equivalent financial instruments in different national markets. 
a common world factor may have little or no ability to explain its expected return (Bekaert and Harvey (1995:403)).”

Reasons for market segmentation can be traced back to investors' inhibitions caused by a lack of local market information, by fear of expropriation, or by discriminatory taxation of foreign investors. Furthermore, official restrictions such as capital controls can restrict foreigners' access to local capital markets or reduce their freedom to repatriate capital and dividends. Some countries, predominantly emerging markets, also formally limit the fraction of a local firm's equity that can maximally be owned by foreign investors.

Empirical findings show that companies resident in not (yet) fully integrated markets suffer from higher costs of equity and lower liquidity in their shares. Not surprisingly, Serra (1999) finds a positive revaluation effect around the announcement date of a cross-listing on a major international stock exchange. ${ }^{8}$ These positive deviations are often explained by the overcoming of market segmentation as a major disadvantage of purely locally listed stocks without the ability to tap into international capital markets. ${ }^{9}$ Thus, overcoming market segmentation by cross-listing shares on well-integrated stock exchanges is beneficial for companies as it reduces their cost of capital.

Information disclosure hypothesis: Companies cross-listing in markets with more demanding disclosure requirements signal their quality to outside investors. Baker, Nofsinger, and Weaver (2002) as well as Lang, Lins, and Miller (2003) show that cross-listings are in

\footnotetext{
${ }^{8}$ For an analysis of price reactions to cross-listings, see Stapleton and Subrahmanyam (1977), Errunza and Losq (1985), Alexander, Eun, and Janakiramanan (1988), Torabzadeh, Bertin, and Zivney (1992), Kadlec and McConnell (1994), Lau, Diltz, and Apilado (1994), Sundaram and Logue (1996), Foerster and Karoly (1999), Miller (1999), Serra (1999), Doukas and Switzer (2000), Errunza and Miller (2000), Bris, Cantale, and Nishiotis (2007), Litvak (2008), Roosenboom and van Dijk (2009), and Sarkissian and Schill (2009).

${ }^{9}$ Hietala (1989) hypothesizes that investors who are restricted from spreading their funds internationally might require a higher rate of return on local stocks, as they are not able to diversify away the specific country risk.
} 
fact followed by greater media attention, broader analyst coverage, better accuracy of analyst forecasts, and higher quality of accounting information.

Investor protection hypothesis: Cross-listing in markets with more demanding regulations and more effective regulatory oversight can also improve investor bonding. Following Doidge, Karolyi, and Stulz (2008), “controlling” shareholders can thereby credibly signal that they will not engage in opportunistic behavior to the detriment of minority shareholders. As a consequence, the stock's attractiveness (and therefore its value) increases from the point of view of foreign as well as local investors.

Market liquidity hypothesis: The liquidity hypothesis assumes that cross-listing in more developed and more liquid equity markets increases liquidity across the board, primarily because foreign investors are now able to build up exposures to companies resident in so far inaccessible markets. The findings of Smith and Sofianos (1997) support this view for the case of corporations cross-listing on U.S. stock exchanges. Increased liquidity, in turn, helps to reduce the cost of capital and thus, to enhance firm value.

According to Kyle's (1985) auction model, liquidity is related to the information environment, specifically the interaction between a risk-neutral market maker, (uninformed) liquidity traders and other (informed) traders. Chowdhry and Nanda (1991) examine this issue in a multi-market context and show that bid-ask spreads respond negatively to increased competition among different market makers.

Liquidity growth can to some extent also be self-perpetuating. Institutional investors typically operate with minimum liquidity constraints, which define the maximum investment for a given stock. Higher turnover, e.g., resulting from a secondary listing, can therefore make the stock available to a wider range of institutional investors. 


\subsection{Reasons to Cross-Delist}

Against the initial trend to cross-list, a considerable number of European (e.g., Ahold, Air France, Bayer, British Airways, Danone, Fiat) as well as emerging market companies have recently decided to withdraw from international stock exchanges such as the NYSE or the LSE. ${ }^{10}$ In view of the reasoning stated so far, terminating the foreign listing should primarily be accompanied by negative side effects, in particular a decrease in the aggregated trading volume and a rise in the company's cost of capital. ${ }^{11}$ Hence the question arises, why are companies abandoning the advantages of a cross-listing? Doidge, Karolyi, and Stulz (2008) argue that a foreign listing adds costs and complexity, which can ultimately harm competitiveness. Compliance with the Sarbanes Oxley Act (SOX) is in this context an oftencited reason why the benefit calculus for cross-listed companies has been reversed.

\section{Determinants of Liquidity (Re-)Allocation}

In retrospect, if liquidity turns out to work against firms' expectations, this can be either due to an overestimation of the cross-listing's net benefits or a subsequent change in the market environment. Consequently, shedding light on the determinants of the liquidity allocation between local and foreign listing is of essential importance. The remainder of this section discusses the relevant factors and derives the corresponding hypotheses to be tested empirically.

Market segmentation: As the local capital market becomes more integrated into the world market, liquidity should start to re-concentrate on the local exchange. This claim is consistent with the information hypothesis, which states that information density with regard

${ }^{10}$ See, e.g., Dobbs and Goedhart (2008) and Knight and Pretty (2005) for an extensive analysis of the motivation behind a foreign delisting.

${ }^{11}$ For an analysis of price reactions to delistings, see Hostak, Lys, and Yang (2006), Marosi and Massoud (2008), Doidge, Karolyi, and Stulz (2008) as well as Fernandes, Lel, and Miller (2010). 
to a given company is highest in its home market. As this information becomes more accessible to foreign investors, more liquidity should flow into the local market.

A second determinant of the liquidity allocation can be traced back to Bekaert and Harvey's (1995) definition of market integration. They consider markets to be integrated if their valuation can (partially) be explained by a common world factor, i.e., if their covariance with a global factor is significantly larger than zero. Investments in stocks or entire markets that display a low covariance with a common world factor should be of special interest for foreign investors as they help to reduce diversifiable risk. If markets start to integrate and stocks' covariances with the global market increase, this diversification potential decreases, and so does foreign investors' interest.

Hypothesis H1.1: The liquidity share in depository receipts is higher for companies locally listed in (semi-)segmented markets than for companies locally listed in integrated markets.

Hypothesis 1.1 refers to DR liquidity measured as a fraction of local liquidity. A decrease in this ratio may be caused by an increase in local liquidity accompanied by a decrease in foreign liquidity. Local and foreign liquidity may, however, also increase simultaneously, but at disproportionate rates. Against this background, our second hypothesis states:

Hypothesis H1.2: The foreign [local] liquidity should be higher [smaller] for companies locally listed in (semi-)segmented markets than for companies locally listed in integrated markets.

Maturity of the local capital market: Domowitz, Glen, and Madhavan (2001) observe that trading costs are inversely related to market capitalization, which, in turn, is an indicator of market maturity. Further, as pointed out by Halling et al. (2008), the market with lower 
trading costs should ceteris paribus attract a higher fraction of total liquidity. However, due to the difficulty of measuring trading costs directly, they suggest using market size (capitalization) as a proxy for market maturity. The next hypothesis follows:

Hypothesis H2: The liquidity share in depository receipts is higher [lower] for companies locally listed in less [more] mature capital markets.

Economic development and regulatory environment of the local market: While the literature employs the qualifiers "developed" and "emerging" markets to explain differences in liquidity allocations, these classifications also relate to the general state of economic and regulatory development. Both aspects need to be disentangled in the analysis. ${ }^{12}$ Listed companies benefit from greater economic stability and a more effective regulatory environment, and will therefore become more attractive investment targets for local as well as foreign investors. The next hypothesis captures this relationship:

Hypothesis H3: An improvement in a country's economic stability [regulatory environment] leads to an increase in local as well as foreign liquidity.

It can further be argued that, in relative terms, the overall effect should work in favor of the local listing. Greater economic stability offers the added benefit of increasing local purchasing power, which should ultimately spill over into local market liquidity. Similarly, strengthening the regulatory environment (e.g., better investor protection schemes) will reduce the objective risk and subjective fear of expropriation, thereby reducing effective

12 The index provider MSCI for instance refers to gross national income (GNI) when evaluating the economic stability of countries. For further information, the reader can refer to the MSCI Market Classification Framework available at www.msci.com. Other index providers such as STOXX Ltd. use external sources such as the International Monetary Fund (IMF) to assess the economic condition of a country. The IMF, in turn, defines its classification system on the basis of a variety of different factors such as the diversification of the economic structure and economic growth (see Nielsen (2011) for a comparison of existing classification systems). 
market segmentation. In this context, Chung (2006) observes that weak investor protection leads liquidity providers to impose higher bid-ask spreads to cover for the greater severity of asymmetric information problems. Conversely, an improvement in the regulatory environment should decrease transaction costs and re-direct liquidity to the local market where the information density is the highest. The next hypothesis follows:

Hypothesis H4: An increase [improvement] in the economic stability [regulatory environment] of a country decreases the share of trading in the foreign capital market.

Concentration effect: A number of theoretical studies predict that trading tends to agglomerate on the exchange, which offers relative informational advantages for traders (see, e.g., Admati and Pfleiderer (1988), Pagano (1989), Chowdry and Nanda (1991)). ${ }^{13}$ In other words, liberated trading across several exchanges should only prevail in the long run if differential trading frictions exist. Empirical findings support this view. Levine and Schmuckler (2006) show for a global sample covering 45 emerging economies that crosslistings trigger liquidity agglomeration in the foreign market. The same conclusion has been derived by Domowitz, Glen, and Madhavan (1998) for a sample of Mexican companies.

Halling et al. (2008) identify a variety of other factors influencing the allocation of trading volume between local and foreign markets. According to their results, the turnover of DR trading as a fraction of local trading volume is larger for companies located geographically closer to the exchange where the DR is traded. Additionally, they find that the share of trading that takes place in the DR is larger for companies based in emerging

${ }^{13}$ See Halling et al. (2008) for a literature overview. As shown by Chowdhry and Nanda (1991), competition between market makers can significantly lower bid-ask spreads, implying positive liquidity effects. On the one hand, Foerster and Karolyi (1998) observe falling spreads for Canadian stocks after a U.S. crosslisting, while, on the other hand, Mittoo (1997) reports increasing trading volumes for companies listed on the Toronto Stock Exchange following a dual listing. The latter is also consistent with the results of Smith and Sofianos (1997) and Bris, Cantale, and Nishiotis (2007) for stocks cross-listed in the United States. 
economies than for companies domiciled in developed countries. Interestingly, considering the time dimension, the relative share of foreign trading increases for emerging market companies and decreases for companies from developed markets. With regard to company characteristics, they observe a higher turnover percentage in DRs for smaller, highly volatile, and technically oriented companies locally listed in developed markets.

Hypotheses $\mathrm{H} 1.1, \mathrm{H} 2$, and $\mathrm{H} 4$ state that the foreign liquidity fraction is higher for companies resident in more segmented markets (H1.1), less developed capital markets $(\mathrm{H} 2)$, and less stable economies that display a poor regulatory environment $(\mathrm{H} 4)$. These assertions can be supported if the liquidity fraction in the local listing is found to be relatively higher (lower) for companies locally listed in more (less) developed markets. From the perspective of the local listing, the concentration effect, if present, should then work relatively more (less) heavily in the direction of the local (foreign) market for developed market companies than for emerging market companies. This leads to the final hypothesis:

Hypothesis H5: For companies locally listed in integrated [(semi-)segmented] capital markets ([less] developed capital markets, [less] stable economies, [less] stable regulatory environment) the liquidity share in the DR decreases [increases] over time.

While hypotheses $\mathrm{H} 1$ to $\mathrm{H} 4$ are based on a cross-sectional perspective, hypothesis 5 additionally takes into account the time dimension. Time is of special importance as it reveals insights into the evolution of liquidity. While the cross-sectional perspective may find that foreign liquidity is higher for companies domiciled in less developed markets, it would not show whether these higher levels of foreign liquidity may be subject to an increase or decrease over time. The hypothesized relationship between the liquidity ratio as a dependent variable, the time elapsed since the initial cross-listing, and the development of the local market is depicted graphically in Figure 1. 


\section{Data and Estimation Strategy}

\subsection{Data}

The empirical analysis is based on a broad data sample, which includes U.S. crosslistings (ADRs) as well as Global Depository Receipts (GDRs) listed in the U.K. ${ }^{14}$ Unlike the majority of the existing literature, this paper therefore also includes the primary trading venue for two of the largest DR markets-India and Russia. Out of a total of 52 (32) cross-listings from India (Russia), 38 (28) DRs are cross-listed in the U.K. The sampling period covers the time period from 2001 to 2011. Cross-listings included in the sample have initially been steadily increasing from 286 in 2001 to 375 in 2007, only to see a drop to 288 between 2008 and 2011.

All exchange-traded DR programs still or formerly listed on the NYSE, the LSI, and LSE have been identified and included in the analysis. The sample consists of a total of 503 cross-listed shares and their local equivalents, covering 40 countries, which results in 35,849 listing-months observations. Out of the total of 503 depository receipts, 186 have been delisted within the eleven years observed. ${ }^{15}$ To prevent distortions coming from de-listings due to corporate actions such as takeovers or insolvencies, DRs are only included in the analysis if the underlying stocks are still traded. Price and volume data are adjusted for corporate actions such as stock splits.

${ }^{14}$ In order to have a reliable source for turnover data, all DR programs included in the analysis are required to be exchange-traded. This includes all GDRs listed on the London-based LSI and LSE exchanges as well as all Level II and Level III ADRs traded on the NYSE and the NASDAQ. OTC-traded Level I ADRs are excluded from the analysis.

${ }^{15}$ The country allocation of the sample, including a differentiation between still-listed and delisted DRs, is provided in Table A.1 in the Appendix. 
The liquidity measure used as a dependent variable is defined as the trading value in monetary units in a foreign or local listing over a period of one month. Trading values are converted to USD based on daily end-of-day spot rates. ${ }^{16}$ To test the hypotheses related to relative liquidity (re-)allocations, the ratio of foreign to local turnover is used.

In order to test the five hypotheses stated above, the following explanatory variables are included in the analysis:

Market segmentation: The state of market segmentation is assessed using different proxy measures compiled by the Economist Intelligence Unit (EIU) and the Political Risk Services (PRS) Group. ${ }^{17}$ A prerequisite for integrated markets is an unrestricted outflow of formerly invested capital. To assess the ease of capital out- and inflows, we utilize capital repatriation (REP) and government policy towards foreign investment (GPFI). The latter explanatory variable captures a dismissive attitude towards foreign investors which hinders capital inflows and should work against market integration. ${ }^{18}$

As the absence of official restrictions (as captured by REP and GPFI) is merely a necessary (and not a sufficient) condition for market integration, the degree of integration is additionally measured by each company's correlation (CORR) with the world market. It is assumed that the higher the co-movement between a stock or local market and the world

${ }^{16}$ The analysis focuses on the value rather than the volume traded because DRs often represent a fraction or a multiple of the underlying stock shares. Thus, traded values are directly comparable without the need to adjust for fractions or multiples.

${ }^{17}$ The Political Risk Services Group (PRS) as well as the Economist Intelligence Unit (EIU) offer country risk analytics widely used in academia as well as by political agencies.

${ }^{18}$ For the purpose of our analysis, the ordinal variables have been converted into binary variables: set to 1 if the country belongs to the top $20 \%$ within the respective scaling and 0 otherwise. As most of the ordinal variables included in the analysis range from values of 1 to 5, the top $20 \%$ represents the "ideal" state, meaning that no restrictions exist. While monthly data is available for the PRS scores, EIU data is only available on an annual basis. Please refer to the Appendix (Table A.2) for a detailed overview of the different indicators published by the EIU and the PRS Group. 
market, the more integrated the company is (see, e.g., Bekaert and Harvey (1995)). ${ }^{19}$ Correlation is measured on the company rather than the country level to account for cases where company-level integration deviates from the integration of the entire market. Given that only few companies cross-list their shares on a foreign exchange, it is also the relevant reference point for foreign investors seeking diversification benefits.

Market maturity: The maturity of the local capital market is measured as the market capitalization of the country (MVALL) as well as the liquidity of the local capital market (MVOLL), both scaled by GDP. The data has been taken from the World Bank database.

Economic stability: The economic stability $(E S)$ of a country is assessed using the PRS economic risk scores. The measure is composed of a weighted average of risk points based on a country's GDP per capita and its real GDP growth, as well as its budget and current account balance, both measured as a percentage of GDP. As an additional measure of a country's economic situation, aggregated savings as a percentage of GDP (GDS) are also taken into account. Consumer confidence (CONF) measures to what extent a country's income is spent on stimulating the economy. In addition, inflation risk (IR), composed by the PRS Group based on annual inflation rates, is included. Inflation diminishes the purchasing power of a country's inhabitants and should consequently decrease the attractiveness of a company active in that country.

Regulatory environment: The state of a country's regulatory frame is evaluated using EIU and PRS scores measuring a country's financial regulatory system (FRS), law and order (LO), as well as the degree of corruption (COR) present in the economy.

Concentration effect: Following Halling et al. (2008), the months elapsed since the initial cross-listing date $(M s L)$ are counted and used as explanatory variable to capture the concentration effect. To test hypotheses H1-H4, the development of a country and its capital

\footnotetext{
${ }^{19}$ Correlation coefficients between each company's stock price movement and the MSCI World index are determined based on weekly returns using a three-year rolling window.
} 
market is measured based on different variables representing the dimensions market integration and market development, as well as a country's economic stability. It is important to note in this context that market development must be modelled as a one- rather than a multi-dimensional measure in order to test whether differences in the influence of time (MsL) on the allocation of liquidity can be explained by different states of market development (H5). Based on the one-dimensional measures of market development provided by $\mathrm{MSCI}^{20}$, the full sample of observations is split into three sub-samples according to the respective countries' state of market development. These measures can be regarded as an aggregation of the disaggregated measures for market development as applied to test hypotheses H1-H4.

Table 1 summarizes the explanatory variables used in the analysis.

\section{$<<<$ Table 1 about here $>>>$}

As pointed out by related studies (e.g., Halling et al. (2008)), various additional factors might influence the liquidity distribution between foreign and local listings. These effects are captured by the following control variables:

Information availability is of essential importance for stock trading and should be positively correlated with transaction volume. Most company-specific information should be available in the respective home market. The geographical distance (DIST) between the local exchange and the location of the foreign exchange (New York or London) is therefore included as a proxy for information availability. Additionally, the simultaneity of trading hours of the respective local and foreign exchanges (SimTr) is included as well. It is assumed that overlapping trading sessions increase the availability of information in the foreign market

${ }^{20}$ MSCI groups countries into three categories: 'developed' (DM), 'emerging' (EM) and 'frontier' (FM) markets with 'developed' being the most mature and 'frontier' the least mature markets. The classification is based on the criteria economic development, size and liquidity requirements, as well as market accessibility. For a detailed breakdown of the respective criteria, the reader is referred to the MSCI Market Classification Framework available at: www.msci.com. 
as market participants trading on the foreign exchange have access to a direct point of pricereference.

Foreign media attention should increase with company size. This effect is captured by including total assets (TA) as a control proxy for size. ${ }^{21}$ Uncertainty with regard to the fair valuation of a company might cause risk-averse investors to shy away from an investment in a given company. To control for this effect, each company's stock price volatility (STDDEV) is included. $^{22}$ Additionally, the exchange rate stability (ERS) of a given country, as composed by the PRS Group based on deviations of currencies from the USD, is taken into account. An increase in the volatility of local FX rates relative to leading currencies tends to depress export volumes and ultimately also local economic growth (see, e.g., De Grauwe and Schnabl (2008)). In addition, unstable exchange rates translate into a higher risk premium required for DR investments.

U.S. markets have been an attractive cross-listing destination for technology-oriented firms because of the perceived agglomeration of sector expertise. The liquidity in the foreign listing of tech companies is therefore supposed to be relatively higher than for companies from other industries. To control for this effect, a binary variable (TECH) is included being 1 if the company belongs to the technology sector (industry code 9000 based on the Industry Classification Benchmark (ICB)) and 0 otherwise. As DR liquidity might also be influenced by the condition of the target market (U.S. or UK), the market capitalization (MVALF) as well as the aggregated turnover (MVOLF) of the respective market, each scaled by GDP, are included as additional control variables.

Further, a dummy variable $(C C)$ for U.S. listing is included, which is 1 if the DR is listed in the U.S. and 0 otherwise. It captures any further differences in the liquidity allocation

${ }^{21}$ Company-level data is taken from Thomson Reuters Datastream and converted into USD values based on end-of-day spot rates.

${ }^{22}$ Volatility figures are determined based on weekly returns calculated over a three-year rolling window. 
related to the target markets which are not captured by the respective market's capitalization and turnover. The period covered in the analysis includes the dotcom as well as the 2007/2008 financial crises. To control for potential distortions associated with the respective market downturns, two binary control variables $(C D$ and $C F)$ are set to 1 during the crisis period (dotcom crisis: 09/2000 - 09/2002; financial crisis: 12/2007 - 02/2009) and 0 otherwise. Lastly, a binary variable $(S D)$, set to 1 if the depository receipt is still actively traded and 0 otherwise, is included to control for potential effects emanating from the delisting process.

\subsection{Estimation Strategy}

In the empirical analysis, we use a panel regression approach to investigate the liquidity differences cross-sectionally and liquidity dynamics over time. The Hausman specification test reveals that the individual effects are correlated with the other regressors. ${ }^{23}$ Therefore, a fixed effects rather than a random effects model is applied. Compared to a standard OLS regression, the fixed effects model estimator is based on the deviation of each observation from its time-mean rather than the observation level itself. This would result in a loss of all explanatory variables whose values are time-invariant (e.g., the distance between the foreign and the local exchange). To overcome this problem, all time-varying and non-binary variables have been transformed into their deviation from time-means while the binary variables themselves enter the regression in their original form. ${ }^{24}$

23 The Hausman specification test has been conducted based on a reduced model excluding those explanatory variables that are constant over time. As those variables are perfectly collinear with company fixed effects, they would consequently be dropped from the fixed effects model. As pointed out by Halling et al. (2008), this would imply that the rank of the variance-covariance matrix of the differences between the coefficients of the fixed and the random effects models deviates from the number of coefficients being tested.

${ }^{24}$ The intention of company fixed effect models is to eliminate level deviations between the respective companies. Binary variables are, however, already normalized in that respect. Furthermore, a transformation would even eliminate information (e.g., in case a binary variable is one and constant over time for one company, and zero and constant over time for another company) as both transformed variables would equal zero. 
Country fixed effects are not included as country dummies lead to high multicollinearity. Binary country variables can be modelled as (near-)linear combinations of the existing variables implying that the other regressors already capture most of the countryspecific variability. ${ }^{25}$ In a similar vein, time fixed effects are not included, as they would absorb most of the information that should be attributed to the time-varying explanatory variables inserted in the model for hypothesis testing.

OLS standard errors are typically unbiased when modeling fixed effects. However, as pointed out by Petersen (2009), this is in fact only true for cases where firm- and/or timeeffects remain fixed. If this assumption does not hold, (e.g., as is the case when a firm effect decays over time), then modeling fixed effects in the regression does not completely remove the correlation among residuals of the same firm in different time periods (firm effect) or among residuals of different firms at the same time (time effects). To account for this problem, heteroskedasticity- and autocorrelation-consistent clustered standard errors that simultaneously cluster by firm and month are used (see Petersen (2009) and Thompson (2011)).

Most of the variables used in the analysis are related to regulatory or macroeconomic factors associated with a given country. It is assumed that liquidity does not react instantly to a change in these factors. Institutional investors especially are bound to a predefined set of exchanges on which they are allowed to trade. Adding new exchanges to their investment universe, e.g., after direct or indirect investment barriers cease to exist, typically takes a few weeks. To account for this delay, time-varying explanatory variables are lagged by one period.

25 As a substitute for country fixed effects, region-dummies have been tested following Halling et al. (2008), defined as 1 if a company is domiciled in a specific region [such as Africa, Asia, Eastern Europe, Western Europe, Middle East, South/Central America] and 0 otherwise. Regional dummy variables, however, also lead to severe multicollinearity and consequently, have been excluded. 
The concentration hypothesis underpinning hypothesis H5 assumes that liquidity, which is concentrated on a given exchange, attracts more liquidity over time. To model these dynamics, the lagged dependent variable is included as a RHS variable as well. The following specification is used to test the hypotheses related to foreign liquidity expressed as a fraction of local liquidity: ${ }^{26}$

$$
\ln L R_{i, t}=\sum_{j=1}^{3} \beta_{j} I M_{i, t-1}+\sum_{k=1}^{2} \beta_{k} M M_{i, t-1}+\sum_{l=1}^{7} \beta_{l} E R_{i, t-1}+\beta_{m} C E_{i, t}+\sum_{n=1}^{12} \beta_{n} C V_{i, t-1}+\beta_{o} \ln L R_{i, t-1}+\varepsilon_{i, t}
$$

where $I M$ comprises the three government policy measures towards foreign investment (GPFI), repatriation (REP), and correlation (CORR) used to test H1. MM represents the capitalization (MVALL) as well as the aggregated turnover (MVOLL) of the local capital market utilized to test $\mathrm{H} 2$. ER includes all previously defined variables used to test the influence of the economic and regulatory development of the local market on the liquidity allocation (H3 and H4). It includes economic stability (ES), gross domestic savings (GDS), consumer confidence (CONF), law and order (LO), degree of corruption (COR), inflation risk (IR), and the financial regulatory system (FRS). $C E$ represents the concentration effect and is captured by the months elapsed since the initial cross-listing (MsL) to test $\mathrm{H} 5 . \mathrm{CV}$ are the control variables. Table 2 provides an overview of the regressors considered in the analysis.

\section{$\ll<$ Table 2 about here $>>>$}

In order to test the hypotheses separately with respect to foreign and the local liquidity (rather than the ratio of both measures), two further regression models are constructed using foreign $\left(L F_{i, t}\right)$ and local liquidity $\left(L L_{i, t}\right)$ as dependent variables, each measured as the sum of

${ }^{26}$ Note that the regression equation does not include a fixed effects parameter. Fixed effects are modeled by the transformation of all time-varying and non-binary variables into their deviations from time-means. Similar to fixed effects parameters, this allows us to control for firm-specific time-invariant effects, such as industry sector classification or the fragmentation of domestic equity markets by, e.g., dark pools or alternative trading systems. 
the monthly turnover. The explanatory variables are identical to the ones included in Equation (1).

\section{Empirical Results}

\subsection{Standard Model}

India and the U.K. are the countries with the largest number of cross-listings, with 51 and 49 DRs respectively. Average values for turnover indicate that local liquidity is significantly higher for developing markets than for emerging markets. The values range from a minimum of $4.2 \mathrm{mn}$ USD per month for companies domiciled in Peru to a maximum of 13.5bn USD per month for companies domiciled in Spain. Average monthly foreign liquidity ranges from a minimum of $2.2 \mathrm{mn}$ USD for Pakistan to a maximum of $945.8 \mathrm{mn}$ USD for Finland. Intuitively, correlations on the company level, averaged per country, tend to be lower the less developed the respective country is. They range from a minimum of $11.2 \%$ for companies domiciled in Pakistan to a maximum of $62.4 \%$ for Spanish companies. Market value scaled by GDP (MVALL) as a measure for the development of the local capital market is lowest for the developing market Hungary with an average market capitalization per GDP of 0.25 and highest for the highly capitalized Hong Kong with an average of 4.45. Economic stability across all sample companies is found to be highest in Norway and lowest in Turkey. The indicator for law and order identifies Colombia as the most risky and Denmark, Sweden, and the Netherlands as the least risky for the sampling period. ${ }^{27}$

Table 3 summarizes the correlation coefficients of all explanatory variables. The coefficients range from a minimum of $\rho=-0.67$ (geographical distance between the local and

${ }^{27}$ See also Table A.1 in the Appendix, which contains a summary of country averages for all variables used in the hypothesis testing. Country averages of PRS and EUI measures have been transformed into ranks with a score of 1 denoting the least risky and most stable country with regard to the respective measure. The underlying country averages are not reported here and are available from the authors upon request. 
the foreign exchange (DIST) and the simultaneous trading hours (SimTR)) to a maximum of $\rho$ $=0.77$ (market value (MVALL) and market volume (MVOLL) of local capital market). The negative correlation between DIST and SimTR makes intuitive sense: the greater the geographical distance, the fewer the simultaneous trading hours between local and foreign exchange. The comparatively high correlation between market value and volume implies that an increase in the capitalization of a market is accompanied by an increase in trading volume. $^{28}$

$\ll<$ Table 3 about here $\gg>$

Table 4 summarizes the regression results. Column 1 includes the regression results based on foreign divided by local liquidity (LR) as the dependent variable; columns 2 and 3 display the regression results for each listing's liquidity (foreign (FL) and local (LL)) separately.

$<<<$ Table 4 about here $>>>$

The remainder of this section presents and discusses the empirical results in conjunction with the previously specified hypotheses. ${ }^{29}$

Market segmentation: In line with H1.1, the ratio of foreign to local liquidity is found to decrease as a consequence of an increase in market integration. Interestingly, the reallocation is not caused by a decrease in foreign liquidity, which could be explained by a potential

28 Variance inflation factors (VIF) have been calculated for each explanatory variable to test for multicollinearity. All VIFs are found to be below 4.2 indicating that no significant multicollinearity exists among the independent variables.

29 The regressions are run with (extended model) and without (core model) the control variables as defined in the previous section. Next to the regression results for the extended model as provided in columns (2), (4), and (6) of Table 4, columns (1), (3), and (5) display the respective results for the core model. The discussion focuses on the extended model. Where the results of the core model deviate significantly from the extended model, it is explicitly mentioned. 
decrease of the stock's diversification potential. It is rather triggered by an increase in local liquidity. A correlation increase by one standard deviation (0.19) leads to an increase in local liquidity by $5.71 \%$. Since foreign liquidity is not affected, the relative allocation (LR) shifts to the benefit of the local listing.

Foreign liquidity is found to be unaffected by other measures of market integration; government policy towards foreign investment (GPFI) and repatriation of capital (REP). This result indicates that foreign investors tend to continue trading cross-listed stocks even when the local market starts to integrate into the world capital market.

Interestingly, an easing of capital repatriation (REP) decreases local trading. Since foreign liquidity is unaffected, the relative liquidity allocation increases in favor of the foreign listing. The shift in liquidity might be due to foreign investors moving away from the local market if repatriation of capital becomes easier. This explanation is further backed by the core model, which shows an increase in foreign liquidity as a consequence of easier capital repatriation. $^{30}$

Maturity of the local capital market: The development of the local capital market is not found to exert a significant influence on the liquidity allocation in the extended model. However, in the core model, the development of the local market, measured by its capitalization scaled by GDP (MVALL), is found to wield a positive and significant influence on the liquidity of the local listing, which supports H2. An increase of MVALL by one standard deviation (0.96) leads, ceteris paribus, to an increase in local liquidity of $10.79 \%$. Given a simultaneous increase in foreign liquidity, the ratio of foreign divided by local liquidity only increases by $6.01 \%$; however this effect is statistically insignificant,. After adding control variables, the positive effect of MVALL on foreign and local liquidity is still

\footnotetext{
${ }^{30}$ When including control variables, the positive effect of REP on foreign liquidity is less pronounced and
} becomes statistically insignificant. 
observable but considerably reduced in its extent, rendering this variable statistically insignificant.

Economic development \& regulatory environment: In support of hypothesis $\mathrm{H} 3$, an increase in the economic stability measure (ES) by one standard deviation (4.10) causes an increase in the local listing's liquidity of $4.54 \%$. This finding supports the assumption that a more stable economy, e.g., as assessed by GDP per capita and GDP growth, increases the flow of money to the local capital market, which, in turn, leads to higher turnover.

With an increase of $2.83 \%$, foreign liquidity also profits from an increase in the economic condition of the local market. The smaller response of foreign compared to local liquidity with respect to ES supports $\mathrm{H} 4$, which states that both listings benefit from improvements in economic stability and that the local listing additionally profits from an increased purchasing power of local investors. In support of $\mathrm{H} 3$, gross domestic savings scaled by GDP as an additional measure for the economic condition of the local market leads to a relative liquidity reallocation in favor of the local market. An increase by one standard deviation from its mean of 0.23 reduces the liquidity ratio by $5.93 \%$.

An improvement in a country's standards with regard to law and order (LO) has a statistically significant but negative influence on foreign liquidity, which also causes the ratio of foreign to local liquidity to decrease. Similarly, the state of the financial regulatory system (FRS) exerts a negative influence on foreign liquidity. These results can be caused by foreign investors abandoning investments in response to diminished growth potential in such countries. All other variables used to assess the influence of economic development and the regulatory system are not found to exert a significant influence on the liquidity allocation.

Concentration effect: Hypothesis H5 states that the influence of time (MsL) on the liquidity allocation depends on the degree of market development. A graphical representation 
of the influence of time on the logarithm of the ratio of foreign to domestic turnover conditional on different degrees of market maturity is depicted in Figure 2.

\section{$<<<$ Figure 2 about here $\gg>$}

In support of $\mathrm{H} 1.1, \mathrm{H} 2$, and $\mathrm{H} 4$, the graphical representation shows that the scaled foreign liquidity increases with declining market development. The share of foreign liquidity, calculated as an average of the first year following the initial cross-listing, is only $4.8 \%$ for companies resident in developed markets (DM); it increases to $18.2 \%$ for emerging markets (EM) and to $22.0 \%$ for frontier market (FM) companies. Over the course of 15 years following the cross-listing, the foreign share remains fairly stable for companies resident in developed markets. In contrast, it increases by two percentage points for emerging market firms and by as much as 22.1 percentage points for frontier market firms (to levels of $20.2 \%$ (EM) and $44.1 \%$ (FM), respectively). The graphical analysis is in line with the findings of Halling et al. (2008), who find an increase over time in foreign scaled by local trading volume for companies domiciled in emerging markets. The trend for developed markets is less clear, being positive for the first half of their sample period ranging from 1980 to 2001 and negative thereafter. Overall, the graphical depiction supports the hypothesis that liquidity attracts more liquidity. Shares of developed market firms that are already heavily traded in the local market start at very low fractions of foreign liquidity. Consequently, they are barely able to increase liquidity in the foreign listing, whereas companies locally listed in frontier markets start at considerably higher fractions of foreign liquidity and display much higher growth rates over time.

To further analyze the influence of time on the liquidity allocation, additional regressions are run based on the respective sub-samples assembled according to the MSCI country classification (DM, EM, and FM). Table 5 provides the regression coefficients of the 
months elapsed since the initial cross-listing $(\mathrm{MsL})$ for the entire sample as well as the three sub-samples.

$<<<$ Table 5 about here $\gg>$

At first glance, the regression results with regard to MsL seem to contradict the graphical representation. Based on the entire sample of observations, MsL is found to exert a statistically significant negative influence on the fraction of foreign liquidity: the ratio decreases by as much as $0.26 \%$ per month. ${ }^{31}$ For developed market companies, the liquidity ratio is unaffected by MsL which corresponds with the graphical representation. In contrast, for developing market companies the ratio is found to decrease significantly, by $0.69 \%$ per month for emerging market firms and $0.37 \%$ per month for frontier market firms.

The source for this apparent contradiction can be found in the application of company fixed effects in the regression model. The insertion of fixed effects effectively downscales the liquidity ratios (LR) of a number of listings that enter our sample after they have already been listed for some time. This relative reduction is especially pronounced within the developing market sub-sample and leads to a decreasing rather than to an increasing trend of LR for the first years following the cross-listing.

A decrease in the ratio of foreign to local liquidity might intuitively be explained by a reallocation of liquidity away from the foreign toward the local listing. The separate examination of foreign and local liquidity reveals that the negative influence of MsL on the LR is primarily driven by a decrease in foreign liquidity without a statistically significant simultaneous increase in local liquidity. While local liquidity is always found to be unaffected by MsL, irrespective of the sub-sample period, the development of foreign liquidity over time

${ }^{31}$ While the overall effect of time elapsed since the initial listing (MsL) on foreign liquidity is negative in the extended model, it is slightly positive in the core model. However, due to the relatively more pronounced increase in local liquidity, the effect of time on the liquidity ratio remains negative in the core model as well. 
depends on the sub-sample under consideration. It decreases for emerging and frontier market firms and remains stable for developed market companies. Interestingly, the decrease is negatively related to local market development (i.e., $0.44 \%$ per month for emerging market firms and $0.57 \%$ per month for frontier market firms). As stated above, the decrease in the liquidity ratio (FL/LL) over time is less pronounced for frontier market firms compared to emerging market firms, while the decrease in foreign liquidity itself (FL) is more pronounced among the frontier market sub-sample. This difference is due to the simultaneous, but statistically insignificant, reaction of local liquidity (LL). LL increases for emerging market firms over time, and thus leads to a negative reaction of FL/LL, while it decreases among frontier market firms, partially offsetting the negative effect on relative liquidity allocation.

Control variables: A number of control variables are found to significantly influence the liquidity allocation between local and foreign listing. Company size as measured by total assets (TA) exerts a positive influence on foreign as well as local liquidity: an increase in firm size of $1 \%$ leads to an increase in foreign liquidity by $0.24 \%$. This finding supports the assumption that information density in a foreign market is higher for larger companies which, in turn, can explain a higher turnover. With an increase of $0.16 \%$, the local liquidity is also found to react positively to an increase in firm size. Due to the simultaneous and even more pronounced increase in foreign liquidity, the ratio of foreign to local liquidity increases by $0.10 \%$. This finding contradicts the result of Halling et al. (2008), who observe a negative relationship between company size and foreign liquidity. This difference can presumably be explained by the extended regional coverage of our sample. It includes companies cross-listed in the U.K., among them large-cap Indian and Russian companies with high foreign liquidity.

Stock price volatility (STDDEV) exerts a negative influence on foreign liquidity: an increase in volatility by one standard deviation (0.025) decreases foreign liquidity by $3.55 \%$. Exchange rate stability (ERS) exerts a significant influence as well. The foreign liquidity of 
companies resident in countries with stable exchange rates is on average $15.05 \%$ higher compared to companies locally listed in countries with comparatively unstable exchange rates. With a relative increase of $7.81 \%$, the local listing's liquidity also profits from an increase in exchange rate stability, but the more exaggerated increase in foreign liquidity leads to a net increase in the ratio of foreign to local liquidity by $7.99 \%$.

Both the capitalization (MVALF) and the turnover (MVOLF) of the foreign market are found to have a positive influence on the turnover of the cross-listing (FL). While the liquidity of the local listing is unaffected by MVALF, it increases with MVOLF. Given the simultaneous increase in foreign as well as local liquidity following an increase in MVOLL, the liquidity ratio (FL/LL) is unaffected by MVOLL, but positively related to MVALF. A more active foreign capital market therefore exerts a positive influence on foreign dual listings. This effect should mainly be caused by uninformed liquidity traders as mentioned by Kyle (1985). The foreign liquidity of companies cross-listed in the U.S. is found to be slightly higher (5.04\%) than for companies cross-listed in the U.K.

In line with the findings of Halling et al. (2008), the distance between the local and the foreign exchange is found to negatively influence foreign liquidity. A one percent increase in the geographical distance reduces foreign liquidity by $0.01 \%$. Lastly, the dotcom crisis has a negative effect on the liquidity of both the foreign and the local listing. With a decrease of $12.23 \%$, foreign liquidity decreases slightly more than local liquidity $(-9.04 \%)$.

\subsection{Robustness Tests}

Repeating the regression with altered settings allows us to examine the robustness of the main results. The first alteration involves measuring integration on the country level based on 
each company's home country's correlation with the world market. ${ }^{32}$ Second, rather than using the binary transformations, we employ the original (non-transformed, continuous) measures taken from the Economist Intelligence Unit (EIU) and the Political Risk Services (PRS) Group. A third adjustment is made with regard to the consideration of the financial crisis. While the standard model controls for the financial crisis in the form of a dummy variable set to 1 in the time period ranging from $12 / 2007$ to $02 / 2009$ and 0 otherwise, the regression is re-run based on a sub-sample that excludes this time period.

Lastly, we adjust the dependent variable used to quantify the liquidity of the local and the foreign listing as well as the ratio of both. Rather than measuring liquidity based on daily trading volume, liquidity is now defined as the price impact of a given stock's turnover. This impact is assessed using the Amihud (2002) Illiquidity Measure (AIM). It considers a stock to be less liquid when a lower turnover is required to achieve a given price change. The AIM therefore measures the absolute change in a stock's return triggered by a given aggregated volume in monetary units traded over a pre-defined period of time.

The AIM of stock $i$ for month $m$ is defined as:

$$
A I M_{i, m}=\frac{1}{D_{i m}} \sum_{t=1}^{D i m} \frac{\left|r_{i t}\right|}{D T V_{i t}}
$$

where $r_{i t}$ and $D T V_{i t}$ are the daily return and the daily dollar trading volume of stock $i$ on day $t ; D_{i m}$ represents the number of days in month $m$ for which a ratio can be derived. ${ }^{33}$

Table 6 provides an overview of the regression models used for the robustness tests as well as a description of the deviation from the standard model. Following the procedure applied when testing the standard model, all regressions are conducted with and without

${ }^{32}$ The correlation coefficients are determined based on weekly returns between MSCI country indices and the MSCI World index over a three year rolling window.

33 The return data required for the AIM computation was available for 31,015 listing-months observations. Thus, the sample is slightly reduced compared to the 35,849 listing-months observations of the standard model. 
control variables. The robustness tests largely support the previously reported results. However, some observed deviations with respect to the influence and statistical significance of the independent variables across the additional empirical model specifications also indicate the sensitivity with which some of the variables react to changes in the model settings. ${ }^{34}$

\section{$\ll<$ Table 6 about here $\gg>$}

Market segmentation: In line with the standard model, an increase in market integration leads to a decrease in the ratio of foreign to local liquidity. In models R2 and R3, foreign scaled by local liquidity decreases with an increase in the stock's correlation with the world market. The same holds true when measuring correlation on the country rather than the company level (R1). This general finding is also supported by regressions run with AIM as an alternative measure (R4). As expected, the illiquidity of the foreign listing is found to vary positively with the stock's correlation with the world market measured on a return basis. ${ }^{35}$

Considering foreign and local liquidity separately reveals an interesting deviation from the results reported in Section 5.1. While models R2-R4 suggest-in line with the results of the standard model - that the decrease in the ratio of foreign to local liquidity is caused by an increase in the local liquidity, model $\mathrm{R} 1$ finds the reallocation to be triggered by a decrease in foreign liquidity. Thus, an increase in a stock's correlation with the world market pushes up the local listing's liquidity. In contrast, an increase in the correlation of the entire local market, as considered by model R1, leads to a decrease in foreign liquidity. Thus, when looking at market-wide rather than single stock correlations, the assumed decrease in foreign liquidity, potentially triggered by a decrease in the diversification potential of DRs, becomes obvious. The difference in the influence of both correlation measures on foreign liquidity

${ }^{34}$ In order to conserve space, the results are made available in the Supplementary Internet Appendix, which can be accessed at https://....

${ }^{35}$ As AIM measures illiquidity, the expected signs of regression coefficients are reversed compared to the standard model. 
might indicate that foreign investors look at entire markets rather than single listings when assessing the diversification potential of DRs.

Maturity of the local capital market: In line with the standard model, the robustness tests support the positive and significant influence of the development of the local market, measured by its capitalization scaled by GDP (MVALL), on the liquidity of the local listing. This finding is consistent across all models considered in this section.

Economic development \& regulatory environment: The robustness tests also confirm the statistically significant influence of economic stability (ES) on foreign and local liquidity, as unfolded by the standard model. Across all four models, the stability of the economy is found to exert a positive influence on both foreign and local liquidity. Gross domestic savings scaled by GDP (GDS) is found to be statistically significant only in model R1.

In line with the results of the standard model, the influence of the variables law and order (LO) and the state of the local market's financial regulatory system (FRS) on foreign scaled by local liquidity is found to be negative and statistically significant across all four additional models. The negative impact of these variables on foreign liquidity itself, as identified by the standard model, is, however, only supported by models R3 and R4. ${ }^{36}$

Concentration effect: The negative influence of time elapsed since the initial cross listing (MsL) on foreign scaled by local liquidity is supported by the robustness checks. All regressions show a negative impact of time on the relative liquidity allocation (FL/LL). They also support the observation that the negative relationship is primarily due to a decrease in foreign liquidity (FL) of companies domiciled in developing rather than developed markets (models R2 to R4). When further dividing developing markets into emerging and frontier markets, the robustness tests indicate that the decrease in FL over time is more consistent within the emerging rather than the frontier market sub-sample. While the negative influence

\footnotetext{
${ }^{36}$ The regression coefficients of all four extended models point to a negative effect of LO and FRS on
} foreign liquidity; however, this effect is found to be statistically significant only in models R3 and R4. 
of MsL on FL within the frontier markets sub-sample is only statistically significant in model $\mathrm{R} 2$, it is significant within the emerging market sub-sample in models R2 to R4.

\section{Conclusion}

Empirical results show that the trading share associated with a foreign listing is negatively related to the degree of market integration measured as the stock price correlation with the world market. This relationship is mainly affected by an increase in local rather than a decrease in foreign liquidity as the degree of market integration increases. Practical conclusions follow for companies resident in segmented markets, which are considering a cross-listing to overcome market segmentation and to lower their cost of capital in the process.

If market segmentation is low but projected to be of a transitory nature, then liquidity can be expected to increase locally as the local capital market integrates over time. In such an environment, a cross-listing can help to overcome a non-persisting weakness of the local market. The empirical results further show that foreign liquidity tends to be largely unaffected by an increase in local market maturity and integration.

Earlier studies (e.g., Levine and Schmuckler (2006)) find a relative increase in foreign trading over time with detrimental effects for the local listing. As a consequence, a foreign listing would only be rational if the expected decrease in the cost of capital weighs more heavily in the cost-benefit calculus than a loss of local liquidity and market visibility. Our empirical results however contradict this finding. Controlling for other factors, the liquidity in local shares remains rather stable with a tendency to slightly increase, whereas foreign liquidity tends to decrease over time. This trend is found to be driven by less developed local capital markets. These results should therefore alleviate fears of losing local liquidity to the foreign listing when local market conditions are not expected to improve in the near future. 
The more important question is whether cross-listings can be rationalized if the liquidity in the foreign listing is expected to decrease over time. The primary motivation of crosslisting a company's stock is the desire to reduce the cost of capital. Foreign liquidity plays an important role in this context. It signals the presence of foreign investors who require a lower premium for country risk. The cost reduction can, however, also be achieved in the absence of the liquidity effect if the cross-listing leads to stricter information disclosure requirements and a strengthening of investor protection in general.

Finally, the empirical results confirm that, next to capital market segmentation, economic stability as well as the reliability of a country's regulatory system play an important role in explaining the spread of liquidity across local and foreign listing. Strengthening the regulatory environment leads to a relative liquidity reallocation caused by a decrease in foreign liquidity. A more stable economic development trajectory offers the additional benefit of attracting more local capital to the equity market. 


\section{Appendix}

Table A.1: Summary of Sample

\begin{tabular}{|c|c|c|c|c|c|c|c|c|c|c|c|c|c|c|c|c|c|c|}
\hline Country & $\begin{array}{l}\text { (Still) } \\
\text { listed } \\
\end{array}$ & $\begin{array}{c}\text { De- } \\
\text { listed }\end{array}$ & Total & FL / LL & FL & LL & GPFI & REP & CORR & MVALL & MVOLL & ES & GDS & CONF & LO & COR & IR & FRS \\
\hline$(1)$ & (2) & (3) & (4) & $(5)$ & (6) & (7) & (8) & (9) & (10) & (11) & (12) & (13) & (14) & (15) & (16) & (17) & (18) & (19) \\
\hline Argentina & 13 & 2 & 15 & 4.29 & 14.5 & 9.5 & 31 & 40 & $31.4 \%$ & 0.35 & 0.03 & 26 & 15 & 36 & 35 & 29 & 39 & 25 \\
\hline Australia & 9 & 11 & 20 & 0.28 & 97.0 & $1,109.1$ & 16 & 25 & $35.0 \%$ & 1.19 & 0.94 & 13 & 16 & 3 & 9 & 8 & 22 & 11 \\
\hline Austria & 0 & 1 & 1 & 0.01 & 3.0 & 540.5 & 16 & 1 & $15.5 \%$ & 0.44 & 0.17 & 10 & 12 & 26 & 1 & 6 & 4 & 11 \\
\hline Belgium & 2 & 0 & 2 & 0.06 & 38.4 & 732.9 & 8 & 21 & $48.2 \%$ & 0.65 & 0.29 & 11 & 19 & 11 & 13 & 13 & 7 & 4 \\
\hline Brazil & 29 & 2 & 31 & 1.11 & 456.2 & 600.1 & 16 & 38 & $49.4 \%$ & 0.58 & 0.28 & 31 & 29 & 39 & 39 & 25 & 33 & 18 \\
\hline Chile & 12 & 8 & 20 & 0.93 & 26.4 & 51.1 & 9 & 18 & $37.5 \%$ & 1.12 & 0.16 & 14 & 10 & 12 & 19 & 15 & 27 & 11 \\
\hline $\begin{array}{l}\text { Colombia } \\
\text { Czech }\end{array}$ & 2 & 0 & 2 & 5.09 & 95.4 & 55.0 & 16 & 31 & $31.3 \%$ & 0.36 & 0.04 & 35 & 32 & 27 & 40 & 23 & 32 & 22 \\
\hline Republic & 2 & 0 & 2 & 0.08 & 11.6 & 274.0 & 10 & 13 & $39.1 \%$ & 0.28 & 0.17 & 28 & 11 & 23 & 13 & 26 & 23 & 25 \\
\hline Denmark & 2 & 1 & 3 & 0.04 & 30.5 & 614.7 & 11 & 11 & $39.5 \%$ & 0.63 & 0.49 & 7 & 17 & 2 & 1 & 2 & 11 & 5 \\
\hline Egypt & 9 & 0 & 9 & 0.86 & 113.1 & 140.4 & 16 & 39 & $20.0 \%$ & 0.63 & 0.27 & 38 & 36 & 19 & 31 & 40 & 36 & 36 \\
\hline Finland & 1 & 3 & 4 & 0.10 & 945.8 & $4,685.6$ & 16 & 1 & $48.5 \%$ & 1.10 & 1.37 & 4 & 14 & 1 & 1 & 1 & 5 & 7 \\
\hline France & 6 & 17 & 23 & 0.04 & 163.8 & $2,747.5$ & 16 & 12 & $49.8 \%$ & 0.82 & 0.81 & 16 & 28 & 30 & 20 & 18 & 9 & 3 \\
\hline Germany & 5 & 11 & 16 & 0.05 & 185.7 & $4,163.3$ & 16 & 1 & $52.2 \%$ & 0.46 & 0.66 & 12 & 22 & 35 & 13 & 9 & 6 & 9 \\
\hline Greece & 3 & 1 & 4 & 0.03 & 11.5 & 538.6 & 16 & 22 & $38.7 \%$ & 0.52 & 0.25 & 33 & 40 & 22 & 30 & 32 & 26 & 25 \\
\hline Hong Kong & 16 & 5 & 21 & 0.20 & 143.2 & $1,026.3$ & 1 & 1 & $33.9 \%$ & 4.45 & 3.76 & 3 & 6 & 7 & 21 & 14 & 8 & 11 \\
\hline Hungary & 3 & 2 & 5 & 0.23 & 59.2 & 396.7 & 7 & 24 & $42.1 \%$ & 0.25 & 0.19 & 36 & 24 & 21 & 26 & 22 & 29 & 21 \\
\hline India & 38 & 13 & 51 & 0.17 & 94.0 & 819.1 & 32 & 32 & $32.1 \%$ & 0.74 & 0.65 & 37 & 8 & 8 & 26 & 33 & 34 & 37 \\
\hline Indonesia & 2 & 0 & 2 & 0.25 & 53.4 & 195.1 & 34 & 34 & $28.3 \%$ & 0.31 & 0.15 & 30 & 7 & 33 & 34 & 36 & 35 & 39 \\
\hline Ireland & 5 & 2 & 7 & 200.03 & 185.7 & 434.6 & 1 & 19 & $37.3 \%$ & 0.45 & 0.25 & 18 & 3 & 4 & 1 & 19 & 25 & 33 \\
\hline Israel & 6 & 6 & 12 & 1.19 & 331.5 & 99.8 & 13 & 26 & $30.7 \%$ & 0.86 & 0.48 & 17 & 33 & 32 & 13 & 21 & 17 & 23 \\
\hline
\end{tabular}

Table continues on the next page. 


\begin{tabular}{|c|c|c|c|c|c|c|c|c|c|c|c|c|c|c|c|c|c|c|}
\hline Country & $\begin{array}{l}\text { (Still) } \\
\text { listed } \\
\end{array}$ & $\begin{array}{c}\text { De- } \\
\text { listed }\end{array}$ & Total & FL / LL & FL & $\mathbf{L L}$ & GPFI & REP & CORR & MVALL & MVOLL & $\mathbf{E S}$ & GDS & CONF & LO & COR & IR & FRS \\
\hline (1) & (2) & (3) & (4) & (5) & (6) & (7) & (8) & (9) & (10) & $(11)$ & (12) & (13) & (14) & (15) & (16) & $(17)$ & (18) & (19) \\
\hline Italy & 4 & 6 & 10 & 0.02 & 63.2 & $4,226.3$ & 34 & 10 & $51.3 \%$ & 0.40 & 0.55 & 23 & 27 & 34 & 28 & 27 & 13 & 25 \\
\hline Japan & 20 & 12 & 32 & 0.04 & 70.3 & $2,361.5$ & 39 & 15 & $39.2 \%$ & 0.81 & 0.93 & 19 & 20 & 38 & 13 & 20 & 1 & 35 \\
\hline Mexico & 20 & 6 & 26 & 18.90 & 204.5 & 149.3 & 16 & 23 & $43.3 \%$ & 0.29 & 0.07 & 29 & 26 & 28 & 36 & 35 & 28 & 16 \\
\hline Netherlands & 3 & 5 & 8 & 0.03 & 164.3 & $2,716.9$ & 1 & 14 & $52.5 \%$ & 0.95 & 1.42 & 9 & 13 & 9 & 1 & 5 & 10 & 8 \\
\hline New Zealand & 1 & 2 & 3 & 0.08 & 25.5 & 232.6 & 15 & 20 & $23.9 \%$ & 0.37 & 0.15 & 15 & 23 & 24 & 8 & 3 & 16 & 1 \\
\hline Norway & 1 & 3 & 4 & 0.03 & 94.9 & $2,887.3$ & 29 & 8 & $46.4 \%$ & 0.63 & 0.73 & 1 & 2 & 6 & 1 & 6 & 14 & 10 \\
\hline Pakistan & 5 & 0 & 5 & 3.50 & 2.2 & 278.7 & 1 & 37 & $11.2 \%$ & 0.28 & 0.37 & 39 & 39 & 40 & 33 & 37 & 37 & 25 \\
\hline Peru & 1 & 1 & 2 & 71.66 & 174.4 & 4.2 & 30 & 36 & $25.8 \%$ & 0.43 & 0.03 & 24 & 25 & 18 & 32 & 28 & 18 & 24 \\
\hline Philippines & 3 & 0 & 3 & 0.91 & 83.3 & 97.8 & 34 & 33 & $27.0 \%$ & 0.49 & 0.09 & 25 & 35 & 14 & 38 & 38 & 30 & 25 \\
\hline Poland & 3 & 4 & 7 & 0.19 & 22.1 & 252.5 & 16 & 27 & $43.3 \%$ & 0.29 & 0.10 & 27 & 30 & 37 & 25 & 34 & 21 & 11 \\
\hline Portugal & 1 & 1 & 2 & 0.02 & 12.9 & 728.0 & 16 & 17 & $38.3 \%$ & 0.39 & 0.25 & 34 & 37 & 25 & 13 & 17 & 20 & 25 \\
\hline Russia & 28 & 4 & 32 & 2.16 & 706.4 & 769.9 & 40 & 30 & $41.0 \%$ & 0.66 & 0.41 & 21 & 4 & 13 & 29 & 39 & 38 & 40 \\
\hline Singapore & 0 & 1 & 1 & 0.34 & 35.2 & 103.5 & 1 & 1 & $39.0 \%$ & 2.34 & 1.22 & 2 & 1 & 10 & 12 & 11 & 1 & 1 \\
\hline South Africa & 6 & 4 & 10 & 2.11 & 201.5 & 413.2 & 34 & 29 & $28.3 \%$ & 2.22 & 1.01 & 32 & 31 & 29 & 37 & 31 & 31 & 25 \\
\hline South Korea & 16 & 10 & 26 & 0.11 & 138.5 & 1413.8 & 38 & 28 & $37.6 \%$ & 0.75 & 1.44 & 8 & 5 & 20 & 22 & 24 & 24 & 38 \\
\hline Spain & 3 & 2 & 5 & 0.01 & 145.0 & $13,498.0$ & 14 & 9 & $62.4 \%$ & 0.87 & 1.37 & 22 & 21 & 16 & 23 & 16 & 19 & 19 \\
\hline Sweden & 1 & 11 & 12 & 0.04 & 197.7 & $2,381.5$ & 12 & 16 & $50.9 \%$ & 0.97 & 1.12 & 6 & 18 & 17 & 1 & 4 & 12 & 17 \\
\hline Switzerland & 4 & 3 & 7 & 0.06 & 288.8 & $3,881.7$ & 16 & 7 & $50.6 \%$ & 2.40 & 2.42 & 5 & 9 & 15 & 11 & 10 & 3 & 6 \\
\hline Turkey & 5 & 4 & 9 & 0.08 & 39.2 & 905.7 & 33 & 35 & $35.0 \%$ & 0.29 & 0.41 & 40 & 34 & 31 & 24 & 30 & 40 & 34 \\
\hline UK & 27 & 22 & 49 & 0.42 & 233.9 & $3,329.4$ & 1 & 1 & $46.7 \%$ & 1.29 & 1.78 & 20 & 38 & 5 & 10 & 12 & 15 & 20 \\
\hline
\end{tabular}

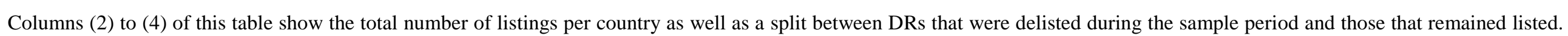

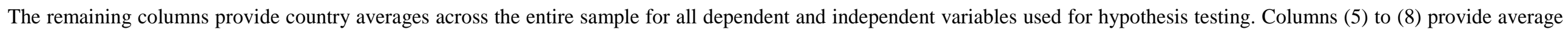

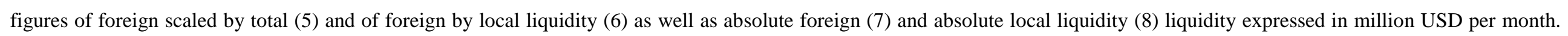

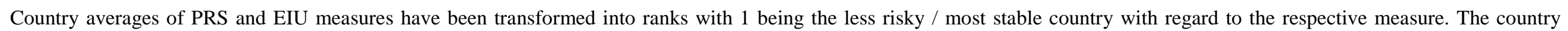
averages of the underlying scores can be requested from the authors. 
Table A.2: EIU and PRS Ratings

\begin{tabular}{|c|c|c|c|}
\hline Risk Indicators & Range & Direction & Description \\
\hline $\begin{array}{l}\text { Economic Stability } \\
\text { (PRS) }\end{array}$ & $1-50$ & (50=high stability) & $\begin{array}{l}\text { The PRS economic risk indicator is composed of an } \\
\text { aggregate of risk points based on a country's GDP per } \\
\text { head, its real GDP growth, its annual inflation rate, its } \\
\text { budget balance as percentage of GDP and its current } \\
\text { account as percentage of GDP. }\end{array}$ \\
\hline Law \& Order (PRS) & $1-6$ & (6=high stability) & $\begin{array}{l}\text { The PRS political risk indicator measures law and } \\
\text { order of a given country. The sub-component "Law" } \\
\text { is an assessment of the strength and impartiality of the } \\
\text { legal system, while the sub-component "Order" is an } \\
\text { assessment of popular observance of the law. }\end{array}$ \\
\hline Corruption (PRS) & $1-6$ & (6=low corruption) & $\begin{array}{l}\text { The PRS political risk indicator measures the extent } \\
\text { of corruption in a given country. }\end{array}$ \\
\hline $\begin{array}{l}\text { Inflation Risk } \\
\text { (PRS) }\end{array}$ & $1-10$ & $(10=$ low risk $)$ & $\begin{array}{l}\text { The estimated annual inflation rate (the non-weighted } \\
\text { average of the Consumer Price Index) is calculated as } \\
\text { a percentage change. The results are then transferred } \\
\text { to risk points. }\end{array}$ \\
\hline $\begin{array}{l}\text { Exchange Rate } \\
\text { Stability (PRS) }\end{array}$ & $1-10$ & $(10=$ high stability $)$ & $\begin{array}{l}\text { The appreciation or depreciation of a currency against } \\
\text { the USD (against the EUR in the case of the USA) } \\
\text { over a calendar year or the most recent 12-month } \\
\text { period is calculated as a percentage change. The } \\
\text { results are then transferred to risk points ranging from } \\
1 \text { (very high risk) to } 10 \text { (very low risk). }\end{array}$ \\
\hline Repatriation (PRS) & $1-4$ & (4=low risk) & $\begin{array}{l}\text { The PRS measure evaluates formal and informal rules } \\
\text { regarding the repatriation of profits, dividends, and } \\
\text { investment capital generated in a foreign country. }\end{array}$ \\
\hline $\begin{array}{l}\text { Consumer } \\
\text { Confidence (PRS) }\end{array}$ & $1-4$ & (4=high confidence) & $\begin{array}{l}\text { The PRS political risk indicator measures confidence } \\
\text { of consumers of a given country. }\end{array}$ \\
\hline $\begin{array}{l}\text { Financial } \\
\text { Regulatory System } \\
\text { (EIU) }\end{array}$ & $1-5$ & (5=high quality) & $\begin{array}{l}\text { The EIU's business environment rankings quantify } \\
\text { the attractiveness of the business environment. The } \\
\text { rating on quality of the financial regulatory system } \\
\text { scores countries between } 1 \text { and } 5 \text {, with } 1 \text { being "very } \\
\text { poor" and } 5 \text { being "very good". }\end{array}$ \\
\hline $\begin{array}{l}\text { Government Policy } \\
\text { towards Foreign } \\
\text { Investment (EIU) }\end{array}$ & $1-5$ & $(5=$ good $)$ & $\begin{array}{l}\text { The EIU's business environment rankings quantify } \\
\text { the attractiveness of the business environment. The } \\
\text { rating on government policy towards foreign } \\
\text { investment scores countries between } 1 \text { and } 5 \text {, with } 1 \\
\text { being "very restrictive" and } 5 \text { being "very } \\
\text { encouraging". }\end{array}$ \\
\hline
\end{tabular}

Source: Political Risk Services Group (PRS) and Economist Intelligence Unit (EIU). 


\section{References}

Admati, A., and P. Pfleiderer (1988). A theory of intraday patterns: volume and price variability. Review of Financial Studies 1(1), 3-40.

Alexander, G.J., C.S. Eun, and S. Janakiramanan (1988). International listings and stock returns: Some empirical evidence. Journal of Financial and Quantitative Analysis 23(2), 135-151.

Amihud, Y. (2002). Illiquidity and stock returns: Cross-section and time series effects. Journal of Financial Markets (5), 31-56.

Amihud, Y., H. Mendelson, and L.H. Pedersen (2005). Liquidity and asset prices. Foundations and Trends in Finance 1(4), 269-364.

Baker, H.K., J.R. Nofsinger, and D.G. Weaver (2002). International cross-listing and visibility. Journal of Financial and Quantitative Analysis 37(3), 495-521.

Bekaert, G, and C.R. Harvey (1995). Time-varying world market integration. Journal of Finance 50(2), 403-444.

Bris, A., S. Cantale, and G.P. Nishiotis (2007). A breakdown of the valuation effects of international cross-listing. European Financial Management 13(3), 498-530.

Chan, J.S.P., Hong, D., and M.G. Subrahmanyam (2007). A tale of two prices: liquidity and asset prices in multiple markets. Journal of Banking and Finance 32, 947-960.

Chordia, T., R. Roll, and A. Subrahmanyam (2000), Commonality in liquidity. Journal of Financial Economics 56(1), 3-28.

Chowdhry, B., and V. Nanda (1991). Multimarket trading and market liquidity. Review of Financial Studies 4(3), 483-511.

Chung, H. (2006). Investor protection and the liquidity of cross-listed securities: evidence from the ADR market. Journal of Banking and Finance 30, 1485-1505.

De Grauwe, P., and G. Schnabl (2008). Exchange rate stability, inflation, and growth in (South) Eastern and Central Europe. Review of Development Economics 12(3), 503-549.

Dobbs, R., and M. Goedhart (2008). Why cross-listing shares doesn't create value. Perspective on Corporate Finance and Strategy, McKinsey and Company, No. 29, 1823.

Doidge, G.C., A. Karolyi, and R.M. Stulz (2004). Why are foreign firms listed in the US worth more? Journal of Financial Economics 71(2), 205-238.

Doidge, G.C., A. Karolyi, and R.M. Stulz (2008). Why do foreign firms leave U.S. equity markets? An analysis of deregistrations under the SEC Exchange Act Rule 12h-6. Working paper, University of Toronto.

Domowitz, I., J. Glen, and A. Madhavan (1998). International cross-listing and order-flow migration: evidence from an emerging market. Journal of Finance 53(6), 2001-2027.

Domowitz, I., J. Glen, and A. Madhavan (2001). Liquidity, volatility and equity trading costs across countries and over time. International Finance 4(2), 221-255.

Doukas, J., and L.N. Switzer (2000). Common stock returns and international listing announcements: conditional tests of the mild segmentation hypothesis. Journal of Banking and Finance 24(3), 471-502. 
Errunza, V., and E. Losq (1985). International asset pricing under mild segmentation: theory and test. Journal of Finance 40(1), 105-124.

Errunza, V., and D.P. Miller (2000). Market segmentation and the cost of capital in international equity markets. Journal of Financial and Quantitative Analysis 35(4), 577600 .

Fernandes, N., U. Lel, and D.P. Miller (2010). Escape from New York: The market impact of loosening disclosure requirements. Journal of Finance 95(2), 129-147.

Foerster, S.R., and G.A. Karolyi (1998). Multimarket trading and liquidity: a transaction data analysis of Canada-U.S. interlistings. Journal of International Financial Markets, Institutions and Money 8(3-4), 393-412.

Foerster, S.R., and G.A. Karolyi (1999). The effects of market segmentation and investor recognition on asset prices: evidence from foreign stocks listing in the United States. Journal of Finance 54(3), 981-1013.

Halling, M., M. Pagano, O. Randl, and J. Zechner (2008). Where is the market? Evidence from cross-listings in the United States. Review of Financial Studies 21(2), 725-761.

Hietala, P.T. (1989). Asset pricing in partially segmented markets: evidence from the Finnish market. Journal of Finance 44(3), 697-718.

Hostak, P., T. Lys, and Y. Yang (2006). Is the Sarbanes-Oxley Act scaring away lemons or oranges? An examination of the impact of the Sarbanes Oxley Act on the attractiveness of U.S. capital markets to foreign firms. Working Paper, Northwestern University.

Jorion, P., and E. Schwarz (1986). Integration vs. segmentation in the Canadian stock market. Journal of Finance 41(3), 603-614.

Kadlec, G.B., and J.J. McConnell (1994). The effect of market segmentation and illiquidity on asset prices: evidence from exchange listings. Journal of Finance 49(2), 611-636.

Knight, R.F., and D.J. Pretty (2005). Evaluating the value and liquidity effects of DRs. A focus on Latin America. Oxford Metrica, 1-12.

Kyle, A. (1985), Continuous auctions and insider trading. Econometrica 53(6), 1315-1335.

Lang, M., K. Lins, and D.P. Miller (2003). ADRs, analysts, and accuracy: Does cross-listing in the US improve a firm's information environment and increase market value? Journal of Accounting Research 41(2), 317-345.

Lau, S.T., J.D. Diltz, and V.P. Apilado (1994). Valuation effects of international stock exchange listings. Journal of Banking and Finance 18(4), 743-755.

Levine, R., and S.L. Schmuckler (2006). Internationalization and stock market liquidity. Review of Finance 10(1), 153-187.

Litvak, K. (2008). The correlation between cross-listing premia, U.S. stock prices, and volume of U.S. trading: a challenge to law-based theories of cross-listing. American Law and Economics Association Papers 84, 1-31.

Miller, D.P. (1999). The market reaction to international cross-listings: evidence from depository receipts. Journal of Financial Economics 51(1), 103-123.

Mittoo, U.R. (1997). Cross-country listing and trading volume: evidence from the Toronto and Vancouver stock exchanges. Journal of International Financial Management and Accounting 8(3), 147-174. 
Nielsen, L. (2011). Classification of countries based on their level of development: how it is done and how it could be done. IMF Working Paper No. 11/31.

Pagano, M. (1989). Trading volume and asset liquidity. Quarterly Journal of Economics 104(2), 255-274.

Petersen, M.A. (2009). Estimating standard errors in finance panel data sets: comparing approaches. Review of Financial Studies 22(1), 435-480.

Roosenboom, P., and M.A. van Dijk (2009). The market reaction to cross-listings: Does the destination market matter? Journal of Banking and Finance 33(10), 1898-1908.

Sarkissian, S., and M.J. Schill (2009). Are there permanent valuation gains to overseas listing? Review of Financial Studies 22(1), 371-412.

Serra, A.P. (1999). Dual-listings on international exchanges: the case of emerging markets' stocks. European Financial Management 5(2), 165-202.

Smith, K., and G. Sofianos (1997). The impact of an NYSE Listing on the Global Trading of Non-U.S. Stocks. NYSE Working Paper 97-02.

Stapleton, R., and M. Subrahmanyam (1977). Market imperfections, capital market equilibrium and corporate finance. Journal of Finance 32(2), 307-319.

Sundaram, A., and D. Loque (1996). Valuation effects of foreign company listings on U.S. exchanges. Journal of International Business Studies 27(1), 67-88.

Torabzadeh, K.M., W.J. Berlin, and T.L. Zivney (1992). Valuation effects of international listings. Global Finance Journal 3(2), 159-170. 
Table 1: Variables Used for Hypothesis Testing

\begin{tabular}{|c|c|c|c|}
\hline Hypothesis & Variable & Abbreviation & $\begin{array}{l}\text { Reference to } \\
\text { Equation (1) }\end{array}$ \\
\hline \multirow{3}{*}{ Market Integration (H1) } & Government Policy towards FI & GPFI & \multirow{3}{*}{$I M$} \\
\hline & Repatriation & $R E P$ & \\
\hline & Correlation & CORR & \\
\hline \multirow{2}{*}{$\begin{array}{l}\text { Maturity of Local Capital } \\
\text { Market (H2) }\end{array}$} & MVAL / GDP (local) & $M V A L L$ & \multirow{2}{*}{$M M$} \\
\hline & MVOL / GDP (local) & MVOLL & \\
\hline \multirow{7}{*}{$\begin{array}{l}\text { Economic and Regulatory } \\
\text { Development of Local } \\
\text { Market (H3/H4) }\end{array}$} & Economic Stability & $E S$ & \multirow{7}{*}{$E R$} \\
\hline & GDS / GDP (Local) & $G D S$ & \\
\hline & Consumer Confidence & CONF & \\
\hline & Law \& Order & $L O$ & \\
\hline & Corruption & COR & \\
\hline & Inflation Risk & $I R$ & \\
\hline & Financial Regulation System & FRS & \\
\hline Concentration Effect (H5) & Months since Listing & $M s L$ & $C E$ \\
\hline \multirow{12}{*}{ Control Variables } & MVAL / GDP (foreign) & $M V A L F$ & \multirow{12}{*}{$C V$} \\
\hline & MVOL / GDP (foreign) & MVOLF & \\
\hline & $\ln ($ Distance $)$ & $\ln (D I S T)$ & \\
\hline & Simultaneous Trading Hours & $\operatorname{SimTr}$ & \\
\hline & $\ln$ (Total Assets) & $\ln (T A)$ & \\
\hline & Standard Deviation & $S T D D E V$ & \\
\hline & Technology Sector & TECH & \\
\hline & Exchange Rate Stability & ERS & \\
\hline & Country (Cross-Listing) & $C C$ & \\
\hline & Status (Listed / Delisted) & $S D$ & \\
\hline & Crises (dotcom) & $C D$ & \\
\hline & Crises (Financial) & $C F$ & \\
\hline Lagged Dependent Variable & Lagged Dependent Variable & $D V_{t-1}$ & \\
\hline
\end{tabular}


Table 2: Definition of Regressors

\begin{tabular}{|c|c|c|}
\hline Variable & Definition & Frequency \\
\hline$G P F I_{c, t}$ & $\begin{array}{l}\text { Government policy towards foreign investment in country } c \text { at time } t \\
\text { (dummy variable equal to } 0 \text { if the EIU criterion is below } 5 \text {, and } 1 \\
\text { otherwise) }\end{array}$ & yearly \\
\hline$R E P_{c, t}$ & $\begin{array}{l}\text { Repatriation of capital from country } c \text { at time } t \text { (dummy variable equal } \\
\text { to } 0 \text { if the PRS criteria is below } 4 \text {, and } 1 \text { otherwise) }\end{array}$ & monthly \\
\hline$C O R R_{i, t}$ & $\begin{array}{l}\text { Correlation of company } i \text { with MSCI World index at time } t \text { (measured } \\
\text { over three year moving window of weekly returns) [deviation from time } \\
\text { mean] }\end{array}$ & monthly \\
\hline$M V A L L_{c, t}$ & $\begin{array}{l}\text { Market capitalization of country } c \text { divided by GDP at time } t \text { [deviation } \\
\text { from time mean] }\end{array}$ & yearly \\
\hline$M V O L L_{c, t}$ & $\begin{array}{l}\text { Market turnover of country } c \text { divided by GDP at time } t \text { [deviation from } \\
\text { time mean] }\end{array}$ & yearly \\
\hline$E S_{c, t}$ & Economic stability of country $c$ in month $t$ [deviation from time mean] & monthly \\
\hline$G D S_{c, t}$ & $\begin{array}{l}\text { Gross domestic savings in country } c \text { divided by GDP at time } t \\
{[\text { deviation from time mean] }}\end{array}$ & yearly \\
\hline$C O N F_{c, t}$ & $\begin{array}{l}\text { Consumer confidence in country } c \text { in month } t \text { (dummy variable equal to } \\
0 \text { if the PRS indicator is below } 3,1 \text { otherwise) }\end{array}$ & monthly \\
\hline$L O_{c, t}$ & $\begin{array}{l}\text { Law and order in country } c \text { at time } t \text { (dummy variable equal to } 0 \text { if the } \\
\text { PRS indicator is below } 6,1 \text { otherwise) }\end{array}$ & monthly \\
\hline $\operatorname{COR}_{c, t}$ & $\begin{array}{l}\text { Corruption in country } c \text { at time } t \text { (dummy variable equal to } 0 \text { if the PRS } \\
\text { indicator is below } 6,1 \text { otherwise) }\end{array}$ & monthly \\
\hline$I R_{c, t}$ & $\begin{array}{l}\text { Inflation risk in country } c \text { at time } t \text { (dummy variable equal to } 0 \text { if the } \\
\text { PRS indicator is below } 8,1 \text { otherwise) }\end{array}$ & monthly \\
\hline$F R S_{c, t}$ & $\begin{array}{l}\text { Financial regulatory system in country } c \text { at time } t \text { (dummy variable } \\
\text { equal to } 0 \text { if the EIU indicator is below } 5,1 \text { otherwise) }\end{array}$ & yearly \\
\hline$M s L_{i, t}$ & Months elapsed since initial listing [deviation from time mean] & monthly \\
\hline$M V A L F_{c, t}$ & $\begin{array}{l}\text { Market capitalization of country in which the DR is cross-listed (U.S. or } \\
\text { U.K.) divided by GDP at time } t \text { [deviation from time mean] }\end{array}$ & yearly \\
\hline$M V O L F_{c, t}$ & $\begin{array}{l}\text { Market turnover of country in which the DR is cross-listed (U.S. or } \\
\text { U.K.) divided by GDP at time } t \text { [deviation from time mean] }\end{array}$ & yearly \\
\hline $\ln \left(D I S T_{i, t}\right)$ & $\begin{array}{l}\text { Natural logarithm of geographic distance between city of local } \\
\text { exchange and London resp. New York }\end{array}$ & -- \\
\hline $\operatorname{SimTr}_{i, t}$ & $\begin{array}{l}\text { Hours of simultaneous trading between local exchange and exchange } \\
\text { where DR is cross-listed }\end{array}$ & -- \\
\hline $\ln \left(T A_{i, t}\right)$ & $\begin{array}{l}\text { Natural logarithm of total assets of company } i \text { in month } t \text { [deviation } \\
\text { from time mean] }\end{array}$ & yearly \\
\hline$S T D D E V_{i, t}$ & $\begin{array}{l}\text { Volatility of company } i \text { in month } t \text { (measured over three year moving } \\
\text { window of weekly returns) [deviation from time mean] }\end{array}$ & monthly \\
\hline $\mathrm{TECH}_{i}$ & $\begin{array}{l}\text { Dummy variable equal to } 1 \text { if company belongs to the tech sector, } 0 \\
\text { otherwise }\end{array}$ & -- \\
\hline$E R S_{c, t}$ & $\begin{array}{l}\text { Exchange rate stability for country } c \text { at time } t \text { (dummy variable equal to } \\
0 \text { if the PRS indicator is below } 8,1 \text { otherwise) }\end{array}$ & monthly \\
\hline$C C_{i}$ & Dummy variable equal to 1 if foreign listing is in the U.S., 0 otherwise & -- \\
\hline$S D_{i}$ & $\begin{array}{l}\text { Dummy variable equal to } 0 \text { if foreign listing has been terminated over } \\
\text { the course of the period observed, } 1 \text { otherwise }\end{array}$ & -- \\
\hline$C D$ & $\begin{array}{l}\text { Dummy variables controlling for the dotcom crisis; equal to } 1 \text { during } \\
\text { the months ranging from } 09 / 2000 \text { to } 09 / 2002,0 \text { otherwise }\end{array}$ & -- \\
\hline$C F$ & $\begin{array}{l}\text { Dummy variables controlling for the financial crisis; equal to } 1 \text { during } \\
\text { the months ranging from } 12 / 2007-02 / 2009,0 \text { otherwise }\end{array}$ & -- \\
\hline$D V_{i, t-1}$ & Dependent variable (LR, FL or LL) lagged by one period & monthly \\
\hline
\end{tabular}


Table 3: Correlation Matrix of Explanatory Variables

\begin{tabular}{|c|c|c|c|c|c|c|c|c|c|c|c|c|c|c|c|}
\hline & GPFI & REP & CORR & MVALL & MVOLL & ES & GDS & $\mathrm{CONF}$ & LO & COR & IR & FRS & MsL & MVALF & MVOLF \\
\hline GPFI & 1 & & & & & & & & & & & & & & \\
\hline REP & 0.4553 & 1 & & & & & & & & & & & & & \\
\hline CORR & 0.0540 & 0.1629 & 1 & & & & & & & & & & & & \\
\hline MVALL & 0.4372 & 0.2989 & -0.0257 & 1 & & & & & & & & & & & \\
\hline MVOLL & 0.4068 & 0.3504 & 0.1232 & 0.7714 & 1 & & & & & & & & & & \\
\hline ES & 0.2235 & 0.4039 & -0.0654 & 0.4072 & 0.3364 & 1 & & & & & & & & & \\
\hline GDS & -0.0643 & -0.0751 & -0.1199 & 0.2045 & 0.0743 & 0.3641 & 1 & & & & & & & & \\
\hline CONF & 0.2691 & 0.1030 & -0.1796 & 0.2110 & 0.1897 & 0.2930 & 0.2081 & 1 & & & & & & & \\
\hline LO & 0.3142 & 0.2256 & -0.0289 & -0.0125 & 0.0249 & 0.2707 & 0.0171 & 0.3914 & 1 & & & & & & \\
\hline COR & -0.0445 & 0.0676 & 0.0351 & 0.0095 & 0.0556 & 0.1534 & 0.0473 & 0.1446 & 0.2690 & 1 & & & & & \\
\hline IR & 0.1751 & 0.3497 & 0.1047 & 0.1504 & 0.1798 & 0.2406 & -0.1049 & 0.0566 & 0.1283 & 0.0345 & 1 & & & & \\
\hline FRS & 0.1990 & 0.3331 & 0.0070 & 0.0114 & 0.0705 & 0.1999 & -0.2368 & 0.2481 & 0.3173 & 0.0615 & 0.1235 & 1 & & & \\
\hline MsL & 0.1003 & 0.1648 & 0.2772 & 0.0141 & 0.0816 & -0.0187 & 0.0102 & -0.0614 & 0.0309 & -0.0311 & 0.0976 & -0.1285 & 1 & & \\
\hline MVALF & 0.0006 & 0.0343 & -0.1798 & 0.1031 & -0.0442 & 0.1651 & 0.0787 & 0.1048 & 0.0204 & 0.0320 & -0.0078 & 0.0516 & -0.1092 & 1 & \\
\hline MVOLF & 0.0452 & 0.0220 & 0.2739 & 0.0733 & 0.2146 & 0.0584 & -0.0017 & -0.1070 & -0.0850 & 0.0000 & 0.0971 & -0.2442 & 0.2190 & -0.5384 & 1 \\
\hline $\ln (\mathrm{DIST})$ & -0.0602 & 0.0269 & -0.1110 & 0.3690 & 0.2498 & 0.1974 & 0.2188 & 0.0966 & -0.0254 & -0.0115 & 0.1347 & -0.1113 & 0.0776 & -0.0502 & 0.1531 \\
\hline $\operatorname{Sim} \mathrm{Tr}$ & -0.0610 & -0.2792 & 0.0714 & -0.3595 & -0.4318 & -0.2617 & -0.1188 & -0.2019 & -0.1595 & -0.0316 & -0.2331 & -0.1182 & -0.0850 & 0.0051 & -0.0650 \\
\hline $\ln (\mathrm{TA})$ & 0.0451 & 0.2137 & 0.5022 & 0.0146 & 0.1807 & 0.0368 & -0.0817 & -0.0596 & 0.0106 & 0.0304 & 0.0826 & 0.0538 & 0.1673 & -0.0435 & 0.0915 \\
\hline STDDEV & -0.0777 & -0.2119 & -0.0663 & -0.0239 & -0.0683 & -0.2452 & 0.0152 & -0.0319 & -0.0007 & -0.0223 & -0.1747 & 0.0177 & -0.1984 & -0.1245 & -0.1384 \\
\hline TECH & -0.0146 & 0.0411 & 0.0430 & 0.0285 & 0.0495 & 0.0868 & 0.0889 & 0.0103 & -0.0066 & 0.0892 & 0.0705 & 0.0313 & -0.0287 & 0.0071 & 0.0040 \\
\hline ERS & 0.0763 & 0.1840 & -0.1023 & 0.0768 & 0.0871 & 0.2794 & 0.1027 & 0.1600 & 0.0894 & 0.0079 & 0.0620 & 0.1188 & 0.0000 & 0.2152 & -0.1741 \\
\hline $\mathrm{CC}$ & 0.1631 & 0.3852 & 0.1579 & 0.1817 & 0.1386 & 0.2269 & -0.1783 & -0.0557 & 0.1573 & 0.0456 & 0.2753 & 0.1516 & 0.1705 & -0.0699 & 0.2511 \\
\hline SD & -0.0222 & -0.1839 & 0.1412 & 0.0212 & 0.0035 & -0.1908 & 0.0283 & -0.0768 & -0.1959 & -0.0922 & -0.1182 & -0.2325 & 0.0446 & -0.1244 & 0.1369 \\
\hline $\mathrm{CD}$ & 0.0072 & -0.0436 & -0.2164 & -0.0951 & -0.0989 & 0.0039 & -0.0851 & 0.0474 & 0.1673 & 0.0671 & 0.0385 & 0.0653 & -0.2010 & -0.0906 & 0.0190 \\
\hline $\mathrm{CF}$ & -0.0001 & -0.0354 & 0.1468 & -0.0278 & 0.1241 & 0.0799 & 0.0383 & -0.0615 & -0.0961 & -0.0281 & -0.0173 & -0.1397 & 0.1242 & -0.6418 & 0.6465 \\
\hline
\end{tabular}

Table 3 continues on the next page. 


\begin{tabular}{|c|c|c|c|c|c|c|c|c|c|c|}
\hline & $\ln (\mathrm{DIST})$ & $\operatorname{SimTr}$ & $\ln (\mathrm{TA})$ & STDDEV & TECH & ERS & $\mathrm{CC}$ & SD & $\mathrm{CD}$ & $\mathrm{CF}$ \\
\hline $\ln (\mathrm{DIST})$ & 1 & & & & & & & & & \\
\hline $\operatorname{SimTr}$ & -0.6651 & 1 & & & & & & & & \\
\hline $\ln (\mathrm{TA})$ & -0.0968 & -0.0800 & 1 & & & & & & & \\
\hline STDDEV & -0.0275 & 0.0580 & -0.2779 & 1 & & & & & & \\
\hline TECH & 0.1168 & -0.1897 & -0.1612 & 0.1262 & 1 & & & & & \\
\hline ERS & -0.0172 & -0.1150 & 0.0368 & -0.1637 & 0.0336 & 1 & & & & \\
\hline $\mathrm{CC}$ & 0.4853 & -0.2598 & 0.0424 & -0.1104 & 0.0014 & -0.0141 & 1 & & & \\
\hline SD & 0.0186 & 0.1313 & 0.1652 & 0.0034 & -0.0819 & -0.0979 & -0.0329 & 1 & & \\
\hline $\mathrm{CD}$ & -0.0082 & -0.0042 & -0.0862 & 0.1411 & 0.0029 & -0.0785 & 0.0250 & -0.1217 & 1 & \\
\hline $\mathrm{CF}$ & 0.0232 & 0.0018 & 0.0564 & -0.1039 & 0.0026 & -0.0922 & -0.0106 & 0.1165 & -0.1388 & 1 \\
\hline
\end{tabular}

Correlation coefficients of all explanatory variables used in the regressions as defined in Equation (1). For better interpretation, the coefficients are based on the actual variables rather than on deviations from time means. The correlation coefficients of binary variables are calculated according to Spearman. 
Table 4: Regression Results for Entire Sample

\begin{tabular}{|c|c|c|c|c|c|c|c|}
\hline \multirow[t]{2}{*}{ Hypothesis } & \multirow[t]{2}{*}{ Variable } & \multicolumn{2}{|c|}{$\ln ($ FL/LL $)$} & \multicolumn{2}{|c|}{$\ln (F L)$} & \multicolumn{2}{|c|}{$\ln (\mathrm{LL})$} \\
\hline & & Core & Extended & Core & Extended & Core & Extended \\
\hline \multirow{3}{*}{$\begin{array}{l}\text { Market } \\
\text { Integration } \\
\text { (H1) }\end{array}$} & GPFI & $\begin{array}{c}-0.0004 \\
(0.0133)\end{array}$ & $\begin{array}{c}0.0015 \\
(0.0138)\end{array}$ & $\begin{array}{c}0.0036 \\
(0.0125)\end{array}$ & $\begin{array}{c}0.0054 \\
(0.0130)\end{array}$ & $\begin{array}{c}0.0071 \\
(0.0096)\end{array}$ & $\begin{array}{c}0.0059 \\
(0.0103)\end{array}$ \\
\hline & $R E P$ & $\begin{array}{c}0.0450 * * * \\
(0.0157)\end{array}$ & $\begin{array}{l}0.0256^{*} \\
(0.0151)\end{array}$ & $\begin{array}{l}0.0283 * \\
(0.0147)\end{array}$ & $\begin{array}{c}0.0013 \\
(0.0153)\end{array}$ & $\begin{array}{l}-0.0116 \\
(0.0117)\end{array}$ & $\begin{array}{l}-0.0217 * \\
(0.0125)\end{array}$ \\
\hline & CORR & $\begin{array}{c}-0.1595 * \\
(0.0901)\end{array}$ & $\begin{array}{c}-0.1661 * \\
(0.0904)\end{array}$ & $\begin{array}{c}0.1660 \\
(0.1015)\end{array}$ & $\begin{array}{c}0.1401 \\
(0.0943)\end{array}$ & $\begin{array}{c}0.3243 * * * \\
(0.0803)\end{array}$ & $\begin{array}{c}0.2946 * * * \\
(0.0755)\end{array}$ \\
\hline \multirow{2}{*}{$\begin{array}{l}\text { Maturity of } \\
\text { Local Capital } \\
\text { Market (H2) }\end{array}$} & $M V A L L$ & $\begin{array}{l}0.0606 * * \\
(0.0277)\end{array}$ & $\begin{array}{c}0.0073 \\
(0.0361)\end{array}$ & $\begin{array}{c}0.1509 * * * \\
(0.043)\end{array}$ & $\begin{array}{c}0.0144 \\
(0.0373)\end{array}$ & $\begin{array}{c}0.1064 * * * \\
(0.0402)\end{array}$ & $\begin{array}{c}0.0104 \\
(0.0306)\end{array}$ \\
\hline & $M V O L L$ & $\begin{array}{c}0.0077 \\
(0.0094)\end{array}$ & $\begin{array}{c}0.0075 \\
(0.0125)\end{array}$ & $\begin{array}{c}0.0065 \\
(0.0138)\end{array}$ & $\begin{array}{c}0.0183 \\
(0.0122)\end{array}$ & $\begin{array}{l}0.0035 \\
(0.014)\end{array}$ & $\begin{array}{c}0.0126 \\
(0.0112)\end{array}$ \\
\hline \multirow{7}{*}{$\begin{array}{l}\text { Economic \& } \\
\text { Regulatory } \\
\text { Development } \\
\text { of Local } \\
\text { Market } \\
\text { (H3/H4) }\end{array}$} & $E S$ & $\begin{array}{c}0.0029 \\
(0.0027)\end{array}$ & $\begin{array}{c}-0.0037 \\
(0.0029)\end{array}$ & $\begin{array}{c}0.0154 * * * \\
(0.0035)\end{array}$ & $\begin{array}{l}0.0068 * \\
(0.0035)\end{array}$ & $\begin{array}{c}0.0149 * * * \\
(0.0036)\end{array}$ & $\begin{array}{c}0.0108 * * * \\
(0.0035)\end{array}$ \\
\hline & $G D S$ & $\begin{array}{l}-0.5628 \\
(0.5668)\end{array}$ & $\begin{array}{c}-0.9587 * \\
(0.5788)\end{array}$ & $\begin{array}{c}0.2043 \\
(0.5293)\end{array}$ & $\begin{array}{r}-0.5863 \\
(0.532)\end{array}$ & $\begin{array}{c}0.6627 \\
(0.5148)\end{array}$ & $\begin{array}{c}0.2181 \\
(0.5223)\end{array}$ \\
\hline & CONF & $\begin{array}{l}-0.0032 \\
-0.0150\end{array}$ & $\begin{array}{c}0.0041 \\
(0.0166)\end{array}$ & $\begin{array}{c}0.0066 \\
(0.0157)\end{array}$ & $\begin{array}{c}0.0250 \\
(0.0166)\end{array}$ & $\begin{array}{c}0.0086 \\
(0.0150)\end{array}$ & $\begin{array}{c}0.0216 \\
(0.0154)\end{array}$ \\
\hline & $L O$ & $\begin{array}{c}-0.0302 * \\
(0.0169)\end{array}$ & $\begin{array}{c}-0.0338 * * \\
(0.015)\end{array}$ & $\begin{array}{l}-0.0312 * \\
(0.0184)\end{array}$ & $\begin{array}{c}-0.0329 * * \\
(0.0167)\end{array}$ & $\begin{array}{l}-0.0101 \\
(0.0161)\end{array}$ & $\begin{array}{l}-0.0057 \\
(0.0168)\end{array}$ \\
\hline & $C O R$ & $\begin{array}{c}0.0290 \\
(0.0277)\end{array}$ & $\begin{array}{c}0.0315 \\
(0.0294)\end{array}$ & $\begin{array}{c}0.0181 \\
(0.0220)\end{array}$ & $\begin{array}{c}0.0168 \\
(0.0237)\end{array}$ & $\begin{array}{c}-0.0029 \\
(0.025)\end{array}$ & $\begin{array}{l}-0.0098 \\
(0.0226)\end{array}$ \\
\hline & $I R$ & $\begin{array}{l}-0.0171 \\
(0.0117)\end{array}$ & $\begin{array}{l}-0.0224 \\
(0.0205)\end{array}$ & $\begin{array}{l}-0.0066 \\
(0.0178)\end{array}$ & $\begin{array}{l}-0.0098 \\
(0.0192)\end{array}$ & $\begin{array}{c}0.0104 \\
(0.0144)\end{array}$ & $\begin{array}{c}0.0108 \\
(0.0184)\end{array}$ \\
\hline & $F R S$ & $\begin{array}{c}-0.0651 * * * \\
(0.0198)\end{array}$ & $\begin{array}{c}-0.0648 * * * \\
(0.0198)\end{array}$ & $\begin{array}{c}-0.0364 * \\
(0.0210)\end{array}$ & $\begin{array}{c}-0.039 * * \\
(0.0197)\end{array}$ & $\begin{array}{c}0.0136 \\
(0.0217)\end{array}$ & $\begin{array}{c}0.0157 \\
(0.0200)\end{array}$ \\
\hline $\begin{array}{l}\text { Concentration } \\
\text { Effect (H5) }\end{array}$ & $M s L$ & $\begin{array}{c}-0.0014 * * * \\
(0.0004)\end{array}$ & $\begin{array}{c}-0.0026 * * * \\
(0.0005)\end{array}$ & $\begin{array}{l}0.0010 * \\
(0.0006)\end{array}$ & $\begin{array}{c}-0.0014 * * \\
(0.0007)\end{array}$ & $\begin{array}{c}0.0023 * * * \\
(0.0006)\end{array}$ & $\begin{array}{c}0.0007 \\
(0.0006)\end{array}$ \\
\hline \multirow{14}{*}{$\begin{array}{l}\text { Control } \\
\text { Variables }\end{array}$} & $M V A L F$ & & $\begin{array}{c}0.1336 * * \\
(0.0611)\end{array}$ & & $\begin{array}{c}0.2931 * * \\
(0.1264)\end{array}$ & & $\begin{array}{c}0.1885 \\
(0.1201)\end{array}$ \\
\hline & $M V O L F$ & & $\begin{array}{c}0.0146 \\
(0.0168)\end{array}$ & & $\begin{array}{c}0.0494 * * \\
(0.0230)\end{array}$ & & $\begin{array}{c}0.0394 * * \\
(0.0175)\end{array}$ \\
\hline & $\ln (D I S T)$ & & $\begin{array}{c}-0.0083 * * \\
(0.0040)\end{array}$ & & $\begin{array}{c}-0.0146 * * * \\
(0.0045)\end{array}$ & & $\begin{array}{l}-0.0071 \\
(0.0044)\end{array}$ \\
\hline & SimTr & & $\begin{array}{l}-0.0020 \\
(0.0017)\end{array}$ & & $\begin{array}{l}-0.0007 \\
(0.0015)\end{array}$ & & $\begin{array}{c}0.0014 \\
(0.0019)\end{array}$ \\
\hline & $\ln (T A)$ & & $\begin{array}{c}0.1007 * * * \\
(0.0295)\end{array}$ & & $\begin{array}{c}0.2372 * * * \\
(0.0300)\end{array}$ & & $\begin{array}{c}0.1630 * * * \\
(0.0326)\end{array}$ \\
\hline & $S T D D E V$ & & $\begin{array}{l}-1.1050 \\
(0.7684)\end{array}$ & & $\begin{array}{c}-1.4213 * * \\
(0.6253)\end{array}$ & & $\begin{array}{l}-0.4522 \\
(0.5855)\end{array}$ \\
\hline & TECH & & $\begin{array}{c}-0.0067 \\
(-)\end{array}$ & & $\begin{array}{l}-0.0109 \\
(0.0089)\end{array}$ & & $\begin{array}{c}-0.004 \\
(0.0123)\end{array}$ \\
\hline & $E R S$ & & $\begin{array}{c}0.0769 * * * \\
(0.0211)\end{array}$ & & $\begin{array}{c}0.1402 * * * \\
(0.0275)\end{array}$ & & $\begin{array}{c}0.0752 * * * \\
(0.0288)\end{array}$ \\
\hline & $C C$ & & $\begin{array}{c}0.0369 \\
(0.0244)\end{array}$ & & $\begin{array}{c}0.0492 * * \\
(0.0209)\end{array}$ & & $\begin{array}{c}0.0124 \\
(0.0107)\end{array}$ \\
\hline & $S D$ & & $\begin{array}{l}-0.0070 \\
(0.0083)\end{array}$ & & $\begin{array}{l}-0.0024 \\
(0.0113)\end{array}$ & & $\begin{array}{c}0.0016 \\
(0.0086)\end{array}$ \\
\hline & $C D$ & & $\begin{array}{l}-0.0429 \\
(0.0316)\end{array}$ & & $\begin{array}{c}-0.1304^{* *} \\
(0.0539)\end{array}$ & & $\begin{array}{c}-0.0947 * * \\
(0.0462)\end{array}$ \\
\hline & $C F$ & & $\begin{array}{c}0.0134 \\
(0.0307)\end{array}$ & & $\begin{array}{c}-0.0562 \\
(-0.0930)\end{array}$ & & $\begin{array}{l}-0.0612 \\
(0.0856) \\
\end{array}$ \\
\hline & $D V_{t-1}$ & $\begin{array}{c}0.6677 * * * \\
(0.0175)\end{array}$ & $\begin{array}{c}0.6620 * * * \\
(0.0171)\end{array}$ & $\begin{array}{c}0.7459 * * * \\
(0.0152)\end{array}$ & $\begin{array}{c}0.7186 * * * \\
(0.0152)\end{array}$ & $\begin{array}{c}0.7257 * * * \\
(0.0206)\end{array}$ & $\begin{array}{c}0.7046^{* * * *} \\
(0.0219)\end{array}$ \\
\hline & $R^{2}$ & 0.4647 & 0.4670 & 0.6066 & 0.6143 & 0.6424 & 0.6477 \\
\hline
\end{tabular}


This table provides the regression coefficients and two-dimensionally clustered standard errors for Equation (1) based on the entire sample. The results for the core model (without control variables) are provided in columns (1), (3), and (5), whereas columns (2), (4), and (6) refer to the extended model including controls. Columns (1) and (2) include regression results based on the log of foreign divided by local liquidity as the dependent variable. Columns (3) and (4) display the regression results for the log of each listing's foreign liquidity while columns (5) and (6) provide the respective results for the log of local liquidity. Note that the standard error of the variable TECH in column (2) is not defined, because the sum of the residuals' variances clustered by month and listing is smaller than the residuals' variance according to White. $* * *, * *$, and $*$ indicate statistical significance at the $1 \%$, $5 \%$, and $10 \%$ level, respectively. 
Table 3: Regression Results for Sub-Samples

\begin{tabular}{llccc}
\hline & & Ln(FL/LL) & Ln(FL) & Ln(LL) \\
\hline \multirow{2}{*}{$M s L$} & Entire & $-0.0026^{* * *}$ & $-0.0014 * *$ & 0.0007 \\
& Sample & $(0.0005)$ & $(0.0007)$ & $(0.0006)$ \\
\hline$R^{2}$ & & 0.4670 & 0.6143 & 0.6477 \\
\hline \multirow{2}{*}{$S L$} & $\mathrm{DM}$ & 0.0000 & 0.0005 & 0.0005 \\
\hline$R^{2}$ & & $(0.0006)$ & $(0.0008)$ & $(0.0008)$ \\
\hline \multirow{2}{*}{$M s L$} & 0.4858 & 0.6469 & 0.6663 \\
\hline$R^{2}$ & $\mathrm{EM}$ & $-0.0069 * * *$ & $-0.0044 * * *$ & 0.0010 \\
\hline \multirow{2}{*}{$M s L$} & $(0.0012)$ & $(0.0012)$ & $(0.0009)$ \\
\hline$R^{2}$ & & 0.4824 & 0.6007 & 0.6655 \\
\hline
\end{tabular}

This table provides the regression coefficients and two-dimensionally clustered standard errors for the variable 'months elapsed since the initial cross-listing' (MsL) based on the entire sample (ES) as well as three sub-samples representing companies locally listed in developed markets (DM), emerging markets (EM), and frontier markets (FM). Column (1) includes the results of the regression based on the log of foreign divided by local liquidity as the dependent variable; columns (2) and (3) display the regression results for the log of each listing's liquidity (foreign and local) separately. The underlying regressions include all explanatory variables also used in the standard regression model of Table 3. For brevity, only the coefficients for MsL are displayed. ***, **, and * indicate statistical significance at the $1 \%, 5 \%$, and $10 \%$ level, respectively. 
Table 6: Regression Models Used for Robustness Tests

\begin{tabular}{ll}
\hline Regression & Deviation from Standard Model \\
\hline R1 & Market integration is measured via correlations of countries rather than stocks with the world market. \\
R2 & The EIU and PRS measures are used in their original rather than in a transformed binary form. \\
R3 & The adjusted sample excludes the financial crisis covering the period from 12/2007 to 02/2009. \\
R4 & $\begin{array}{l}\text { Liquidity in the foreign and the local listing is measured based on Amihud's illiquidity measure } \\
\text { (AIM) rather than with stock turnover. }\end{array}$ \\
\hline
\end{tabular}

This table provides an overview of the adjusted regression models composed in order to test the robustness of the results derived in the context of the standard model specified and explained above. 
Figure 1: Hypothesized Liquidity Allocation

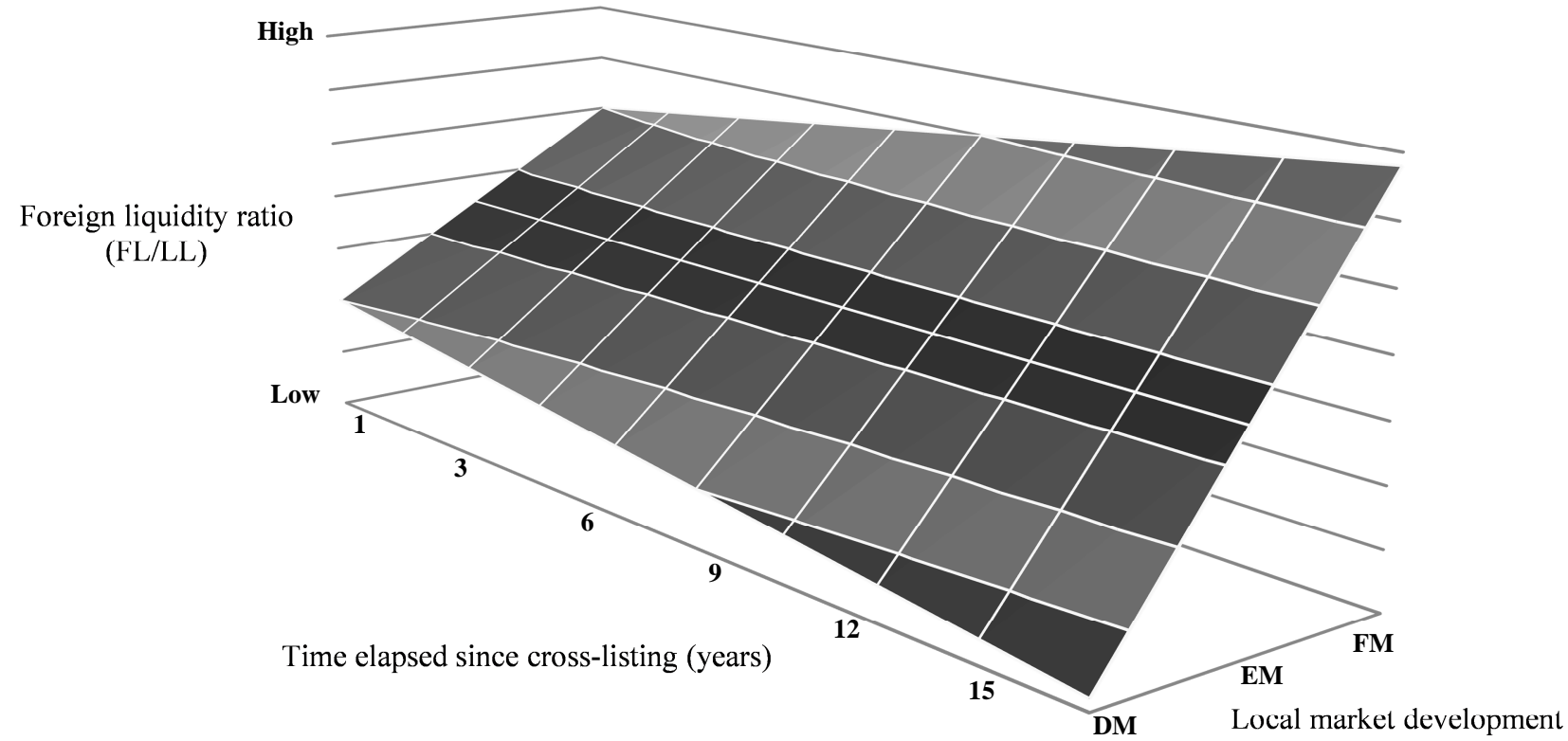

This figure shows the liquidity allocation between the local and the foreign listing (LR) depending on (1) the time elapsed since the initial cross-listing and (2) the state of the development (MSCI classification: developed (DM) / emerging (EM) / frontier (FM)) of the local market as hypothesized in H1-H4. 
Figure 2: Empirical Liquidity Allocation

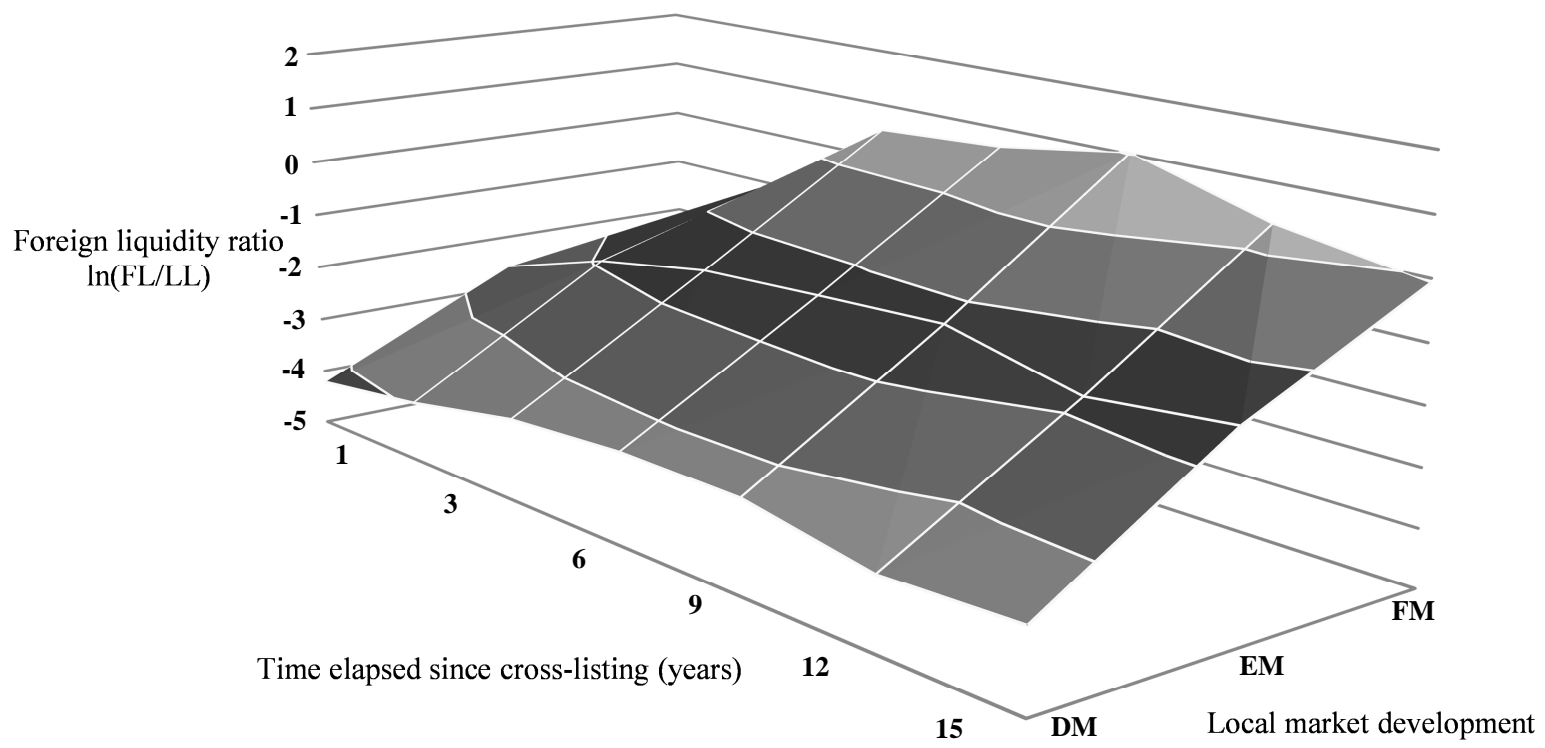

This figure shows the actual liquidity allocation between the local and the foreign listing (LR) depending on (1) the time elapsed since the initial cross-listing and (2) the state of the development of the local market (MSCI classification: developed (DM) / emerging (EM) / frontier (FM)). 